IZA DP No. 6138

Educating Children of Immigrants:

Closing the Gap in Norwegian Schools

Bernt Bratsberg

Oddbjørn Raaum

Knut Røed

November 2011 


\title{
Educating Children of Immigrants: Closing the Gap in Norwegian Schools
}

\author{
Bernt Bratsberg \\ The Ragnar Frisch Centre for Economic Research \\ Oddbjørn Raaum \\ The Ragnar Frisch Centre for Economic Research \\ Knut Røed \\ The Ragnar Frisch Centre for Economic Research \\ and IZA
}
Discussion Paper No. 6138
November 2011

\author{
IZA \\ P.O. Box 7240 \\ 53072 Bonn \\ Germany \\ Phone: +49-228-3894-0 \\ Fax: +49-228-3894-180 \\ E-mail: iza@iza.org
}

\begin{abstract}
Any opinions expressed here are those of the author(s) and not those of IZA. Research published in this series may include views on policy, but the institute itself takes no institutional policy positions.

The Institute for the Study of Labor (IZA) in Bonn is a local and virtual international research center and a place of communication between science, politics and business. IZA is an independent nonprofit organization supported by Deutsche Post Foundation. The center is associated with the University of Bonn and offers a stimulating research environment through its international network, workshops and conferences, data service, project support, research visits and doctoral program. IZA engages in (i) original and internationally competitive research in all fields of labor economics, (ii) development of policy concepts, and (iii) dissemination of research results and concepts to the interested public.
\end{abstract}

IZA Discussion Papers often represent preliminary work and are circulated to encourage discussion. Citation of such a paper should account for its provisional character. A revised version may be available directly from the author. 


\section{ABSTRACT \\ Educating Children of Immigrants: Closing the Gap in Norwegian Schools ${ }^{*}$}

Children of immigrant parents constitute a growing share of school cohorts in many OECD countries, and their educational performance is vital for successful social and economic integration. This paper examines educational outcomes of first and second generation nonOECD immigrants in Norway. We show that children of immigrants, and particularly those born outside Norway, are much more likely to leave school early than native children. Importantly, this gap shrunk sharply over the past two decades and second generation immigrants are now rapidly catching up with the educational performance of natives. For childhood immigrants, upper secondary completion rates decline with age at arrival, with a particularly steep gradient after age seven. Finally, we find that immigrant-native attainment gaps disappear when we condition on grade points from compulsory school.

JEL Classification: J15, I21, I24

Keywords: immigrant children, educational attainment, school performance

Corresponding author:

Bernt Bratsberg

The Ragnar Frisch Centre for Economic Research

Gaustadalléen 21

0349 Oslo

Norway

E-mail: bernt.bratsberg@frisch.uio.no

\footnotetext{
${ }^{*}$ We are grateful to Lena Nekby for helpful comments. We acknowledge funding from the Norwegian Research Council (grant \#202513) and NORFACE (grant \#415). The paper is part of the activities of the centre of Equality, Social Organization, and Performance (ESOP), University of Oslo. Data made available by Statistics Norway have been essential for this research.
} 


\section{Introduction}

The labor market performance of immigrants plays a central role in the overall economic impacts and the distributional effects of international mobility. The labor market outcomes of immigrants themselves and their children are likely to feed back into the barriers that receiving countries invoke to restrict immigration inflows. Over the past decades the immigrant population shares have grown substantially in most high-income countries. Even more striking, the composition of the immigrant population has changed radically with increasing inflows from low-income source countries (Bauer et al., 2000; Blau et al., 2008). In most Northern European host countries, employment and wages of immigrants from lowincome countries fall short of those of natives with comparable levels of education and experience. $^{1}$

From a long-term perspective, the consequences of immigration will depend fundamentally on the performance of the next generations. Offspring of immigrant parents constitute a significant and steadily increasing fraction of the present and future populations of many of the high-income receiving countries. Human capital accumulation is crucial for adult economic performance and social integration, even outside the labor market. Indeed, convergence of educational attainment across generations to that natives is commonly seen as a key indicator of successful integration and several analysts emphasize education as the key pathway for economic integration of immigrants and their descendants (Card and Schmidt, 2003; Card, 2004).

Among immigrant groups from most low-income source countries, arrival in Europe or North America involves a dramatic change in access to and quality of educational institutions across generations. If the educational environment matters, one would expect children of immigrants to outperform their parents and the association of attainment across generations should be weaker for immigrants than for natives (Dustmann and Glitz, 2011). ${ }^{2}$ Studies that compare educational attainments among first and second generation immigrants confirm these

\footnotetext{
${ }^{1}$ Recent studies that document large labor market disparities between natives and immigrants from low-income source countries include Algan et al. (2010) for France, Germany and the UK, Nielsen et al. (2003) for Denmark, Barth et al. (2004) and Bratsberg et al. (2010a) for Norway, Åslund and Rooth (2007) for Sweden, and Sarvimäki (2011) for Finland.

${ }^{2}$ Tests score gaps between majority and ethnic minority children in the UK decline with age, suggesting a role for teacher and school behavior in explaining ethnic differences in educational attainment (Dustmann et al., 2010).
} 
predictions. Algan et al. (2010), for example, show that across the first two generations most immigrant groups in France and Germany catch up with natives, and that the superior attainment of immigrants in the UK is maintained in the second generation. In the United States, education levels are typically much lower among immigrants from developing countries than other groups, with smaller differences between natives and the U.S. born children of immigrant parents from these same countries (Card et al., 2000; Trejo, 2003; Chiswick and DebBurman, 2004). ${ }^{3}$ Similar patterns are documented for the immigrant populations of Canada (Sweetman and Dicks, 1999), Sweden (Urban, 2011), and Switzerland (Bauer and Riphahn, 2007). ${ }^{4}$

Across host countries, differences in educational outcomes by country of origin are large. Using international achievement data, Schnepf (2007) and Dustmann et al. (2011) find that test scores measured at ages 9 to 15 of children born to immigrant parents typically are much lower than those of children of native parents. Comparisons across host countries show that the gap is wider the larger the difference in attainment between immigrant and native parents, reflecting intergenerational correlations in educational outcomes. Schneeweis (2011) concludes that test score differences between immigrant and native children are smaller in host countries with an early school starting age. In studies from Northern and Central Europe, a substantial part of the immigrant-native differential at age 15 disappears when the authors condition on parental education and occupational status; see, e.g., Tables 4.2 and 4.3 of Dustmann et al. (2011) and Table 2 of Liebig and Widmaier (2009).

Because childhood immigrants arrive at different ages, the heterogeneity in educational outcomes among child immigrants extends beyond differences associated with country of origin and parental socioeconomic position. Late arrival means fewer years of exposure to the higher quality learning environment and that the prime age for language adaption may have passed. Using data from Sweden, Böhlmark (2008; 2009) identifies a substantial negative

\footnotetext{
${ }^{3}$ A broader literature studies the intergenerational economic progress of children of U.S. immigrants, see, e.g., Borjas (1994; 2006), Card et al. (2000), and Zhou (1997).

${ }^{4}$ Several of the papers published in the Journal of Population Economics symposium on "Second-generation immigrants and the transition to ethnic minorities," address educational attainments across generations in the immigrant population; see, in particular, Nielsen et al. (2003), Riphahn (2003), and van Ours and Veenman (2003).
} 
effect of age at immigration on educational performance at age $16 .{ }^{5}$ Böhlmark also identifies a critical arrival age of nine years, as childhood and youth immigrants who arrive at an older age have substantially lower grade points than their younger peers. Those arriving after the age of nine appear to catch up with the younger arrivals, however, as educational attainment in young adulthood exhibit less co-variation with age at arrival in the Swedish data than grade points at age 16 (Böhlmark, 2009).

This paper examines educational outcomes in Norway for children of immigrants from lowincome countries, focusing on the importance of being born in Norway relative to arriving as a childhood immigrant. Because children of immigrants from low-income source countries still form a young population group in Norway, our choice of outcome measure is completion of upper secondary education within five years of compulsory education (typically observed at age 21). A key question is whether any native-immigrant differential has changed over time, which we study by looking at upper secondary completion rates of the 15 cohorts that graduated from compulsory education between 1990 and 2004. Access to individual level data for two generations enables us to study the transmission of educational attainment across generations. A fundamental challenge is to disentangle the effects of immigrant background and influences from other family-related factors. Many prior studies ignore essential problems associated with controlling for other observable socio-economic background characteristics. For example, we show that imposing a similar coefficient structure on family characteristics (identified by variation across majority group families) exaggerates estimates of the impact of differential family resource environments.

Our most central finding is that there is indeed evidence of the educational performance of children of immigrants gradually catching up with that of native children during our data period. This is particularly evident for Norwegian-born children of immigrant parents, but we also uncover some indication of progress for children born abroad. Not surprisingly, children's school outcomes are closely related to their parents' resources, as captured by their earnings or educational attainment. But changes in the composition of these resources cannot explain the relative improvement in school performance of children of immigrants; to the contrary, we find evidence that immigrant parents have fallen behind native growth in family

\footnotetext{
${ }^{5}$ See also the U.S. evidence on age at immigration and adult wages in Bratsberg and Ragan (2002), Gonzalez (2003), and Bleakley and Chin (2004); Cortes (2006) examines age at immigration and test scores of U.S. immigrants.
} 
earnings, if anything contributing to a negative development in the educational performance of their children. For children born abroad, the age at immigration is of critical importance. In particular, educational performance declines steeply with each year the child does not attain Norwegian schools. Finally, we provide evidence that the probability of completing upper secondary education relates closely to performance during the final year of compulsory education, as measured by grade points. Conditional on grade points from compulsory school, there is in fact virtually no difference between immigrants and natives, and family background becomes much less important (and irrelevant for the children of immigrants). By implication, if policy makers were to succeed in improving the compulsory school performance of children of immigrants they would also come far in terms of getting immigrant youth successfully through upper secondary education.

\section{Overview}

In Norway, like in most other Northern European countries, large-scale immigration from low-income countries commenced three to four decades ago. Today's cohorts with immigrant parents therefore remain relatively young, but the numbers that graduate from compulsory education are now growing rapidly; see Figure 1. In 1980, the share with immigrant parents among youth coming out of Norwegian compulsory schools was less than one percent and dominated by those with parents from the OECD area. Twenty-nine years later, eight percent of the compulsory school graduating cohort consisted of children of immigrant parents born in a non-OECD country. Within the non-OECD group, the composition is changing rapidly as children born in Norway to immigrant parents (second generation), who accounted for less than one percent of the overall graduating cohort as recently as 1995, made up 3.5 percent in 2009, and, based on the resident population as of 2008, is projected to constitute ten percent of the graduating cohort in 2024. In comparison, offspring of immigrants also made up ten percent of all native-born children in the United States in the mid-1990s (Card et al., 2000). Hence, successful integration of this group of children in the school system is important, not only because it will facilitate economic assimilation of the immigrant population, but because it will also affect the overall economy.

An important "early indicator” of final educational attainment is completion of upper secondary education. Completion of the upper secondary level is viewed as a key to success in the Norwegian labor market, and it is a major policy priority to raise the completion rate. 
Fig 1: Children of immigrants in compulsory school graduating cohorts 1975-2009, and projection 2010-2024

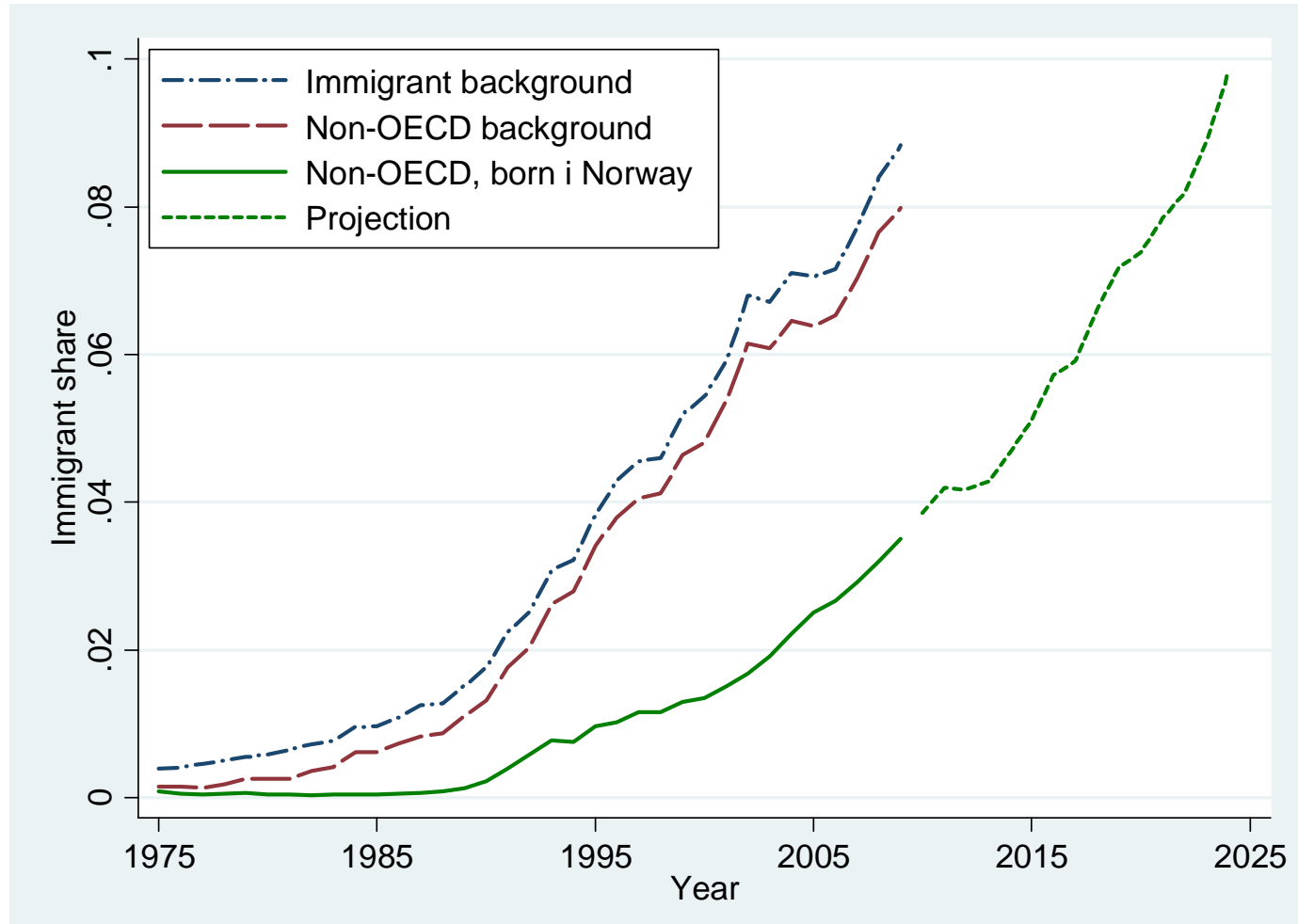

Note: "Immigrant background" denotes both parents born abroad and no Norwegian-born grandparents. "NonOECD" excludes pre-1994 member countries of the OECD except Turkey. Projections for 2010-2024 are based on the 2008 resident population aged to 16 .

Upper secondary education is a requirement for enrollment in higher education, and studies find high labor market returns to the upper secondary diploma (e.g., Dagsvik et al., 2011). Since 1994, all children in Norway have been legally entitled to free upper secondary education upon graduation from compulsory school. As a result of the 1994 reform, the fraction of pupils dropping out directly after compulsory education fell from five to three percent (Raaum et al., 2009; Table 1). The statutory duration of upper secondary education is three or four years, depending on academic or vocational track (see also the descriptions of the Norwegian educational system in Fekjær, 2007, and Støren and Helland, 2010). Any discrepancy in attainment across groups will of course reflect a combination of differences in both entry and completion patterns.

Many students delay their completion of upper secondary education beyond the statutory duration (see, e.g., Bratsberg et al 2010b). For this reason, we will use completed upper secondary education within five years (of graduating from compulsory school) as the key 


\section{Fig 2: Share of compulsory school cohort with completed upper secondary education} within five years, by immigrant status

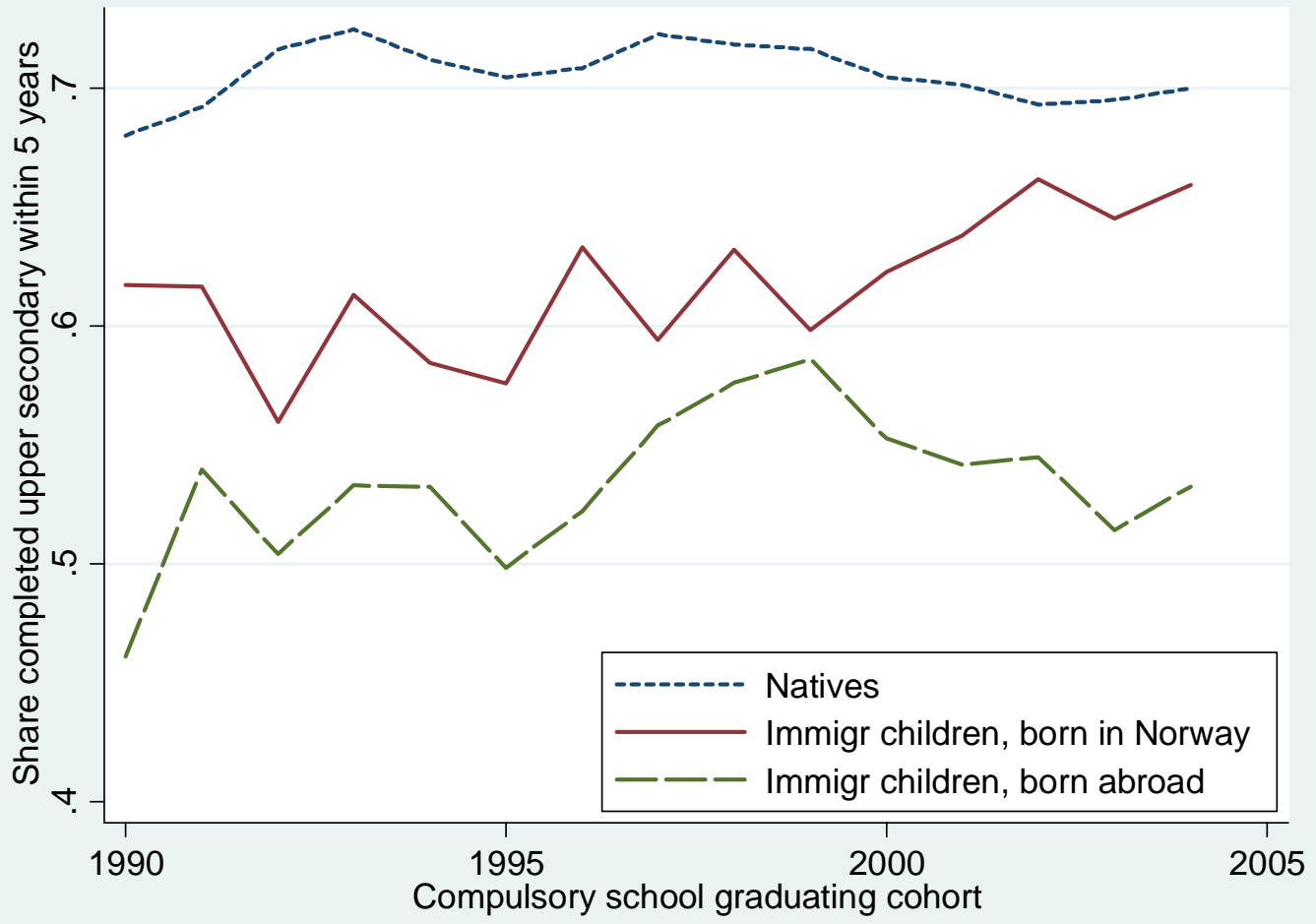

Note: Samples are restricted to those 15-17 when leaving compulsory school. Native sample is restricted to those with two Norwegian-born parents and immigrant samples to those with two foreign-born parents from nonOECD countries. Samples exclude those who died or spent a full calendar year abroad within five years of compulsory education, and immigrant samples are further limited to those below 14 at entry and with at least 3 years in Norway at the time of compulsory school graduation.

educational attainment indicator in our analyses. ${ }^{6}$ Figure 2 displays how this indicator has evolved for the compulsory school graduating cohorts from 1990 through 2004 for three different groups: natives (those born in Norway with two native-born parents) and children of immigrant parents born in Norway and abroad, respectively. (Sample construction is explained in detail in section 3.) Because of high out-migration rates that complicate the study of long-term integration (Bratsberg et al., 2007), and because of their relatively low numbers (refer back to Figure 1), we exclude children of immigrants from pre-1994 OECD member countries (except Turkey).

The figure illustrates a number of important empirical patterns. First, there are significant differences in completion rates between the three groups. The completion rate is much higher

\footnotetext{
${ }^{6}$ None of our key findings are affected if we instead choose a longer interval such as seven or eight years, but sample sizes are severely reduced as we are forced to drop one graduating cohort from the data for each additional year of the interval.
} 
for natives than for childhood immigrants, with children born in Norway to immigrant parents somewhere between the two. Second, the completion rate for the Norwegian-born children of immigrant parents seems to be catching up with that of native children, particularly during the last 5-10 years of the observation period. And third, the completion rate for those born abroad improved during the latter half of the 1990s, but has deteriorated after that. A fourth and particularly interesting pattern is that, for natives, the completion rate has held remarkably stable around 70 percent over the 15-year period. Despite growing up in more educated and wealthier families, several education reforms aimed at raising the completion rate, and significant increases in school expenditures, completion rates among native children hardly budged over the period and remain low when compared to other similar countries (OECD, 2011).

Educational attainment convergence across generations is illustrated in Figure 3, where the center of each circle shows the fraction by source country of immigrant parents and their children who have completed upper secondary education. While natives are located near the 45-degree line with completion rates around 70 percent in both generations, attainments tend to be significantly higher among immigrant children born in Norway compared to their parents (Panel A). The improvement is particularly large for groups within low parental attainment suggesting that the move to a new environment actually enhanced the opportunities for their offspring even if they do not completely match the attainment of children of native parents. For childhood immigrants, overall educational progress across generations is less pronounced although the figure illustrates significant intergenerational mobility in that educational differences among children are much smaller than among their parents. High intergenerational mobility implies a low association between children’s and parent's outcomes. In Figure 3, the regression line relating completion rates of children to those of their parents has a slope of 0.3 in both panels, showing substantial intergenerational education mobility in the Norwegian immigrant population. ${ }^{7}$

\footnotetext{
${ }^{7}$ Because parental education is measured by the maximum attainment of mother and father, the data in Figure 3 understate the overall educational progress across generations. In their cross-country study of intergenerational mobility, Raaum et al. (2007) find that the correlation coefficient between the educational attainment of mothers and daughters, and that between fathers and sons, is approximately 0.4 in Norway, the Unites Kingdom, and the United States.
} 


\section{Fig 3: Intergenerational mobility by source country. Fraction with completed upper} secondary education, immigrant parents and their children

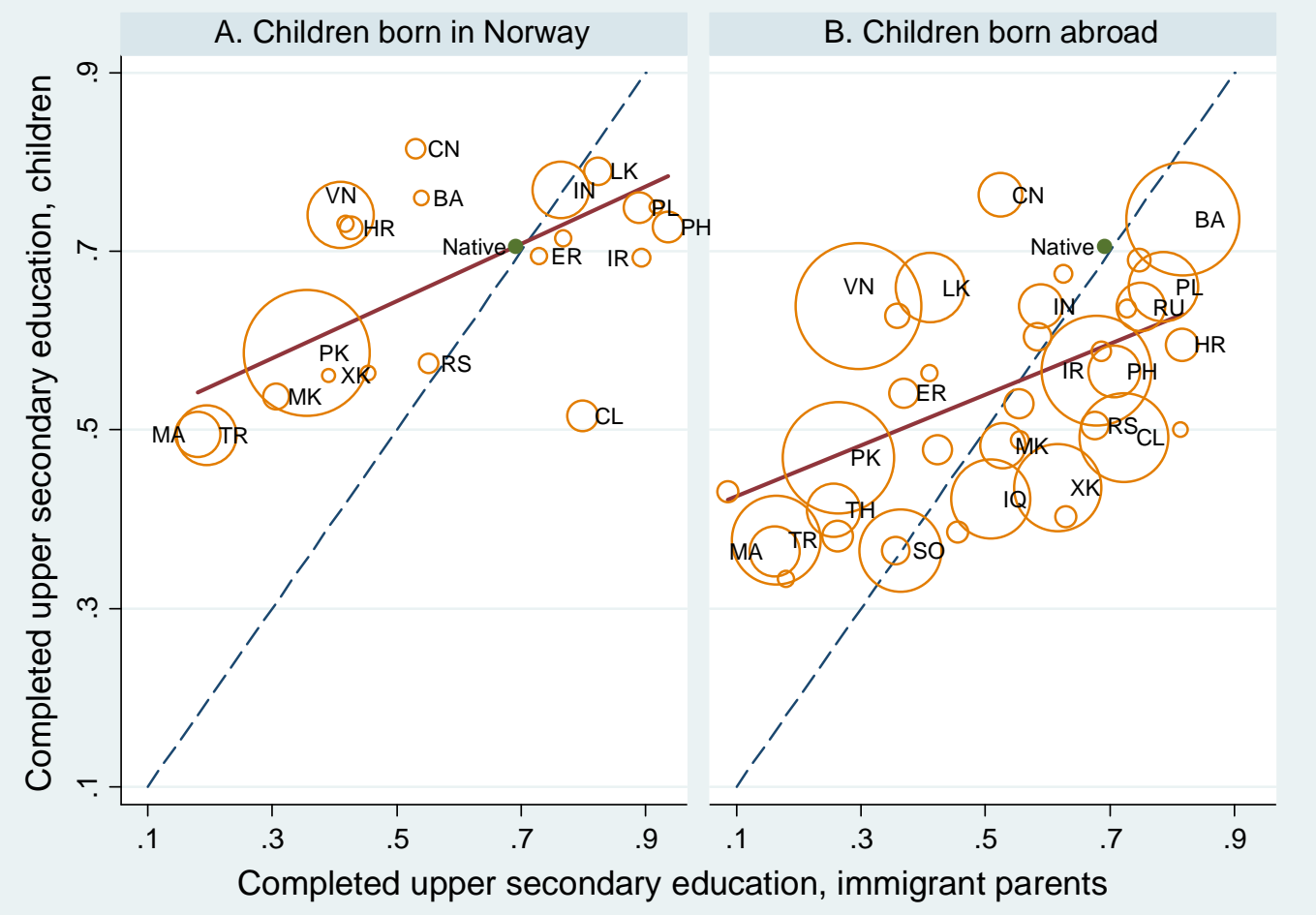

Note: Completion rates for parents give the fraction of immigrant children with at least one parent whose educational attainment is upper secondary or higher. Completion rates for children list the fraction that completed upper secondary education in Norway within five years of compulsory school. Size of scatter point is proportional to cell size; only cells with at least 30 observations are shown. Data limited to non-OECD countries and Turkey. See also note to Table 1. Scatter point labels and values are listed in the appendix.

The purpose of the present paper is to shed light on the mechanisms that have determined the developments shown in Figure 2 and the intergenerational mobility patterns implicit in Figure 3. Policy makers have made large efforts to speed up the integration processes in Norwegian schools; inter alia, by legislating all adolescents the right to upper secondary education, by providing compensating resources to schools with large shares of ethnic minority children, by offering instruction in the mother's language, and by expanding the supply of subsidized institutional child care (there is now 100 percent coverage for children above age one). In addition, to encourage minority participation some school districts with particularly large fractions of immigrant children provide pre-school child care free of charge during core hours (Drange and Telle, 2010).

An important question is whether the apparent improvement over time in the schooling performance of immigrant-background children born in Norway shows that such policy efforts eventually pay off? Or can the development illustrated in Figure 2 be explained by 
other factors, such as better integrated and more resourceful parents, with longer experiences in Norway, or perhaps secular change in the mix of source countries? Why do immigrant outcomes fall below those of natives in the first place? Is it related to their parents' performance in the Norwegian labor market or to their country of origin? How important are such factors as age at immigration and the duration of their parents stay in Norway?

We address these questions by means of merged administrative register data for the cohorts leaving compulsory education between 1990 and 2004. Prior studies that examine early school leaving in Norway identify immigrant background as a predictor of non-completion of upper secondary education; see Støren and Helland (2010) and Markussen et al. (2011). Both of these studies are based on cohorts of upper secondary school entrants or pupils leaving compulsory education around the year 2000. ${ }^{8}$ Two distinguishing features of the present study is that our data cover a total of 15 cohorts and that we follow pupils who leave compulsory schooling and will therefore capture any differential dropout in the transition from compulsory to upper secondary education.

\section{Data}

The data we use in the present paper are based on merged administrative registers, primarily the population register and the national database for education statistics (Vangen, 2007). From the education database we first extracted records for all children who graduated from compulsory education (i.e., $9^{\text {th }}$ grade) between 1975 and 2009. We then merged these records with the central population register, which contains data on country of birth and the date of entry supplied by the immigration authorities. The population register also lists immigrant status of parents as well as "country background," for our purposes defined as own country of birth if born abroad or mother's country of birth if born in Norway. (The variable gives country of birth of mother's mother if the mother is Norwegian born and in some cases country of birth of father, but we do not use this information in the present study.) From these records we keep individuals with both parents born abroad, which we label "immigrant background,” and those born in Norway with both parents also Norwegian born, labeled "natives.” Children with one foreign-born and one native parent are not included in the

\footnotetext{
${ }^{8}$ Fekjær (2007) studies educational attainment of children of immigrants from Pakistan, Turkey, and India born before 1982. Reisel and Brekke (2010) examine dropout from higher education among minority students who enrolled in university education between 1990 and 1998.
} 
analysis sample. We further split the children of immigrant parents into two groups, those born in Norway (i.e., second generation) and those born abroad. Finally, we drop children with an immigrant background from the OECD area (but keep those from Turkey).

Because of small immigrant sample sizes in the graduating cohorts from the 1970s and 1980s (see Figure 1), we restrict our analysis samples to those who left compulsory school after 1989. And, because we track individuals for five years post lower secondary school, data availability through 2009 limits the samples to the graduating cohorts from before 2005. In result, the analysis data consist of the 15 cohorts that left compulsory education between 1990 and 2004. We further limit the analysis samples to those who graduated between the ages of 15 and 17 (in fact, 98 percent of the sample turned 16 during the graduation year), and to those who did not spend a full calendar year abroad nor die within five years of compulsory school. For those born abroad, we also require that they must have been present in Norway for at least three years at the time of compulsory graduation, which means that the maximum age at immigration in our sample is thirteen.

The data thus include information about upper secondary school completion (within five years of compulsory education) collected from the education database, gender, and family background. From the income register of the tax authority, we next extracted annual earnings for each of the parents covering the ten-year period ending the year of graduation from compulsory school, inflated earnings to 2009 values using the base amount of the national pension system, took the average for each parent (accounting for any parental mortality), and computed a measure of parental earnings as the average earnings of mother and father (or as the earnings of the single parent when only one was present during the ten year period). For immigrant parents, we followed the exact same procedure and computed average earnings covering the full ten-year compulsory school period. The exception is parents who arrived in Norway after their child turned seven (who make up 34 percent of the immigrant sample). For these parents we only use the years they were actually present in Norway when computing parental earnings. ${ }^{9}$

\footnotetext{
${ }^{9}$ The reasons for considering a ten-year period when computing parental earnings are two-fold. First, we seek to measure parental resources for the full duration of compulsory schooling. And, second, using a ten-year periodas opposed to parental earnings the year the child left compulsory schooling, as is the common practice in the literature-has been shown to reduce attenuation bias from measurement error in estimates of intergenerational associations (see, e.g., Bratsberg et al., 2007). The fact that 34 percent of the immigrant parents arrived after their child reached school age, and therefore are observed for fewer than ten years, hints that measurement error might be a greater concern for our estimates of effects of parental resources in the immigrant sample than for
} 
We further collected data on educational attainment for parents from the national education database. For native parents, education data typically stem from the records of Norwegian educational institutions or the state educational loan fund. For immigrant parents without Norwegian schooling or student loans, the education data come from various additional sources, including self-reported attainment in immigrant admission and census records as well as two surveys administered by Statistics Norway to all residents with missing education records in 1990 and 1999, and from the agency that certifies foreign education of health workers. We collapse parental education into a single measure based on the highest observed attainment of mother or father. For the last four graduation cohorts (i.e., 2001-2004), we also have access to grade points obtained in compulsory school. Grade points are given as the total of grades in 11 subjects, each on a scale from 1 to 6 .

Descriptive statistics for our analysis samples are provided in Table 1. In total, we have 736,845 observations, of which 8975 are for those with a non-OECD immigrant background and born in Norway, and 18,102 are for non-OECD immigrant children born abroad. As the table shows, the rates of upper secondary education completion within five years of compulsory education range from 54 percent for children born abroad to 71 percent for native children. The three groups differ markedly in terms of parental background characteristics, with the immigrant samples tending to have parents with much lower education and earnings compared to the native sample. In fact, fully 65 percent of immigrant children born abroad and 46 percent of those born in Norway, have parental earnings that fall in the bottom ten percent of the native parental earnings distribution. Similarly, immigrant children are overrepresented in the lowest parental education bracket. For the four cohorts with grade point data, the average for natives (43.5) exceeds that of immigrant-background children born in Norway by about two points, whose average again exceeds that of those born abroad by three grade points. Finally, Pakistan, Vietnam, Turkey, Bosnia and Herzegovina, and Iran make up the major source countries in the immigrant samples.

natives. We find no indication, however, that estimates are impeded by attenuation bias as coefficient estimates of immigrant parental earnings largely remain unaffected when we restrict the immigrant sample to those observed for at least ten years in Norway. Note also that no parents in our sample are observed for fewer than three years and that 90 percent of the immigrant parents are observed for at least five years. 
Table 1: Descriptive Statistics

\begin{tabular}{|c|c|c|c|}
\hline & \multirow{2}{*}{$\begin{array}{l}\text { Native } \\
\text { Children } \\
(1)\end{array}$} & \multicolumn{2}{|c|}{ Children of immigrants } \\
\hline & & $\begin{array}{c}\text { Born in Norway } \\
(2)\end{array}$ & $\begin{array}{c}\text { Born Abroad } \\
(3)\end{array}$ \\
\hline $\begin{array}{l}\text { Completed upper secondary education } \\
\text { within } 5 \text { years of compulsory }\end{array}$ & 0.706 & 0.626 & 0.539 \\
\hline Female & 0.489 & 0.489 & 0.482 \\
\hline \multicolumn{4}{|l|}{ Parental earnings } \\
\hline Mean & 336,782 & 197,601 & 136,800 \\
\hline Standard deviation & 166,353 & 141,460 & 122,821 \\
\hline Share in $1^{\text {st }}$ decile of native earn distr & 0.100 & 0.460 & 0.654 \\
\hline \multicolumn{4}{|l|}{ Parent's highest educ attainment: } \\
\hline Primary or less & 0.095 & 0.420 & 0.374 \\
\hline Lower secondary & 0.213 & 0.076 & 0.050 \\
\hline Upper secondary & 0.319 & 0.200 & 0.226 \\
\hline Tertiary, first stage & 0.274 & 0.201 & 0.197 \\
\hline Tertiary, second stage & 0.099 & 0.057 & 0.082 \\
\hline Missing & 0.000 & 0.047 & 0.070 \\
\hline \multicolumn{4}{|l|}{ Grade points compulsory school } \\
\hline Mean & 43.5 & 41.6 & 38.6 \\
\hline Standard deviation & 9.3 & 9.3 & 9.6 \\
\hline Age at immigration & & & 7.440 \\
\hline \multicolumn{4}{|l|}{ Major source countries: } \\
\hline Pakistan & & 0.411 & 0.095 \\
\hline Vietnam & & 0.114 & 0.119 \\
\hline Turkey & & 0.091 & 0.060 \\
\hline India & & 0.081 & 0.015 \\
\hline Morocco & & 0.052 & 0.019 \\
\hline Chile & & 0.024 & 0.059 \\
\hline Iran & & 0.008 & 0.092 \\
\hline Bosnia and Herzegovina & & 0.006 & 0.097 \\
\hline Observations & 709,768 & 8975 & 18,102 \\
\hline
\end{tabular}

Note: Samples consist of youths leaving compulsory education ( $9^{\text {th }}$ grade) at age 15-17 between 1990 and 2004. Native sample is restricted to those with two Norwegian-born parents and immigrant samples to those with two foreign-born parents from non-OECD countries. Samples exclude those who died or spent a full calendar year abroad within five years of compulsory education, and immigrant samples are further limited to those below 14 at entry and with at least three years in Norway at the time of compulsory school graduation. Parental earnings are inflated to 2009 values using the base amount of the Norwegian pension system and are measured during the ten-year period prior to graduation from compulsory school, accounting for any parental mortality. Earnings are averaged across parents. For immigrant parents who arrived before their child reached school age (66 percent of the immigrant sample), earnings are computed using the full ten-year period. For those who arrived after their child turned seven, earnings are averaged across the years they are observed in Norway. Grade points from compulsory school are available for the 2001-2004 cohorts only; observation counts are 186 231, 3905, and 6966 for the native and two immigrant subsamples with grade points data, respectively, covering 98 percent of the native and 97 of the immigrant samples in the relevant years.

In sum, the descriptive statistics document important differences in educational outcomes by immigrant status, but also large differences in parental resources. In the next section, we examine the relationships between parental resources and educational outcomes in detail. 


\section{Regression analysis}

In this section, we present results from regression analyses aimed at identifying the determinants of lower and upper secondary school performance among immigrant and native children. We first examine upper secondary school completion for all of the cohorts in our data set, focusing on the role of family resources and on the identification of catching-up trends for immigrant children. We then turn to the determinants of school performance at age 16 measured by grade points for the last four cohorts of the data period, and also examine the relationship between grade points at age 16 and subsequent completion of upper secondary school. Next, we address the role of age at immigration. Finally, we take a look at education outcome differentials across source countries.

\subsection{Completion of upper secondary education}

In this subsection, we first present the results from linear probability regression models with upper secondary education completion (within five years of compulsory school) as the dependent variable. We focus on four parameters:

i) the average differential (over all cohorts) between children born in Norway to immigrant and native parents,

ii) the additional average differential for children born abroad,

iii) the average annual change in the impact of immigrant background for those born in Norway (the catching-up rate), and

iv) the average additional annual change in the impact for immigrant children born abroad.

We estimate these parameters and examine their estimation sensitivity in a series of regressions distinguished by the selection of control variables and the way they are allowed to affect the outcome of interest. Our main results are presented in Table 2.

For the baseline model reported in column (1), we have only included gender and 15 cohort dummy variables in addition to the four variables of direct interest. The cohort dummies are included to control for general time developments in completion rates; i.e., changes in the school system and labor markets that are common to those with native and immigrant backgrounds. As the column shows, the estimated average difference in completion rates between immigrant-background children born in Norway and natives is 7.9 percentage points, while the difference between children born abroad and natives is 16.6 percentage points 
Table 2: Upper secondary completion regression results

\begin{tabular}{|c|c|c|c|c|c|c|c|}
\hline & (1) & (2) & (3) & (4) & (5) & (6) & (7) \\
\hline $\begin{array}{l}\text { Immigrant } \\
\text { Background }\end{array}$ & $\begin{array}{l}-.079 \\
(.005)\end{array}$ & $\begin{array}{l}-.067 \\
(.006)\end{array}$ & $\begin{array}{c}.051 \\
(.006)\end{array}$ & $\begin{array}{l}.003 \\
(.006)\end{array}$ & $\begin{array}{l}.002 \\
(.006)\end{array}$ & $\begin{array}{l}-.038 \\
(.005)\end{array}$ & $\begin{array}{l}-.106 \\
(.018)\end{array}$ \\
\hline $\begin{array}{l}\text { Immigrant* } \\
\text { Born abroad }\end{array}$ & $\begin{array}{l}-.087 \\
(.006)\end{array}$ & $\begin{array}{l}-.106 \\
(.007)\end{array}$ & $\begin{array}{l}-.060 \\
(.007)\end{array}$ & $\begin{array}{l}-.076 \\
(.007)\end{array}$ & $\begin{array}{l}-.075 \\
(.007)\end{array}$ & $\begin{array}{l}-.089 \\
(.007)\end{array}$ & $\begin{array}{l}-.031 \\
(.014)\end{array}$ \\
\hline $\begin{array}{l}\text { Immigrant* } \\
\text { Trend/10 }\end{array}$ & $\begin{array}{l}.069 \\
(.012)\end{array}$ & $\begin{array}{c}.063 \\
(.012)\end{array}$ & $\begin{array}{c}.083 \\
(.012)\end{array}$ & $\begin{array}{l}.075 \\
(.012)\end{array}$ & $\begin{array}{l}.058 \\
(.012)\end{array}$ & $\begin{array}{l}.068 \\
(.012)\end{array}$ & $\begin{array}{l}.101 \\
(.019)\end{array}$ \\
\hline $\begin{array}{c}\text { Born abroad* } \\
\text { Trend/10 }\end{array}$ & $\begin{array}{l}-.044 \\
(.015)\end{array}$ & $\begin{array}{l}-.034 \\
(.016)\end{array}$ & $\begin{array}{l}-.038 \\
(.015)\end{array}$ & $\begin{array}{l}-.037 \\
(.015)\end{array}$ & $\begin{array}{l}-.001 \\
(.015)\end{array}$ & $\begin{array}{l}-.014 \\
(.015)\end{array}$ & $\begin{array}{l}-.023 \\
(.024)\end{array}$ \\
\hline Controls & Baseline & $\begin{array}{c}\text { Baseline + } \\
\text { Country }\end{array}$ & $\begin{array}{c}\text { Baseline + } \\
\text { Country }+ \\
\text { Parental } \\
\text { earnings } \\
\text { (common } \\
\text { coeffs) }\end{array}$ & $\begin{array}{c}\text { Baseline + } \\
\text { Country }+ \\
\text { Parental } \\
\text { earnings } \\
\text { (separate } \\
\text { coeffs) }\end{array}$ & $\begin{array}{c}\text { Baseline + } \\
\text { Country + } \\
\text { Parental } \\
\text { education } \\
\text { (common } \\
\text { coeffs) }\end{array}$ & $\begin{array}{c}\text { Baseline + } \\
\text { Country + } \\
\text { Parental } \\
\text { education } \\
\text { (separate } \\
\text { coeffs) }\end{array}$ & $\begin{array}{c}\text { Baseline }+ \\
\text { Family } \\
\text { fixed } \\
\text { effects }\end{array}$ \\
\hline
\end{tabular}

Note: Standard errors are listed in parentheses. Baseline controls include gender and 15 cohort effects; "country" 131 country fixed effects; "parental earnings" 10 earnings intervals given by deciles of the native distribution; and "parental education" 5 levels plus missing education. In columns (2)-(7), the coefficient of "immigrant background" is computed as the difference between the sample mean fixed effects in the immigrant and native subsamples. In addition, in columns (4) and (6) the coefficient of "immigrant background" is averaged across ten income and five education levels, weighted by the native frequency distribution. The regressions have 736,845 observations, except for in column (7) which is based on 512,874 children from 224,077 families with multiple siblings in the data.

(7.9+8.7). Turning to the estimated trend effects, we note that the completion rate for immigrant children born in Norway catches up with that of native children by 0.7 percentage point per year, whereas for those born abroad the catching-up rate is $0.25(0.69-0.44)$ percentage point per year. These numbers are significant, both from a substantive and from a purely statistical point of view. When we add 131 dummy variables for country background to the regression in column (2), it is evident that Norwegian-born children of immigrants perform a bit better, while immigrants born abroad perform somewhat worse than indicated by the estimates in column (1). In other words, childhood immigrants are on balance born in countries with slightly higher completion rates than the immigrant parents of children born in Norway. Importantly, the positive catching-up estimates in column (1) and the positive trends depicted in Figure 2 are not the consequence of secular change in the source-country composition of the immigrant population.

Columns (3)-(6) list results from regression models where we control for parental resources, in terms of earnings or educational attainment; see the table note for details. In columns (3) 
and (5) the specification follows the common practice in the literature and imposes the restriction that parental resources play the exact same role in forming educational outcomes for immigrant and native children (see, e.g., Dustmann et al., 2011; van Ours and Veenman, 2003; and Schnepf, 2007). As the columns show, controlling for parental resources with the restrictive parameter specification has a huge effect on the estimate of the average impact of having an immigrant background. To illustrate, the estimated disadvantage of 6.7 percentage points reported in column (2) is turned around to an advantage of as much as 5.1 percentage points in column (3), where we have controlled for parental earnings. Taken at face value, differences in parental earnings not only explain the disparity of immigrant attainment—when we compare immigrant and native children with similar parental earnings, immigrant children do significantly better than native children. Can we conclude from this that children born in Norway to immigrant parents actually will outperform native children if families were provided similar economic resources? The answer to this question is no, and the reason why we cannot rely on the results reported in columns (3) and (5) is that the models turn out to be grossly misspecified. The problem is that parental resources do not affect immigrants and natives in the same way. Imposing a common parameter structure will therefore "overcontrol” for differences in family resources.

In Figures 4 and 5, we show how parental resources are predicted to affect completion rates of immigrant and native children when the effects are estimated separately for each group. It is clear that whether we look at earnings or education as indicators of parental resources, their effects on the offspring's completion rates are much larger for natives than for immigrants. For example, comparing children in the ninth and second deciles of the (native) earnings distribution, native children in the upper tail have a 22 percentage points higher completion rate than those in the lower tail, compared to a ten percentage points difference among immigrant children. Numerous studies of family background and offspring educational outcomes remind us that correlations between the two only partly reflect causal impacts of parental earnings or education on offspring outcomes (see, e.g., the discussions in Björklund and Salvanes, 2011, and Holmlund et al., 2011). These observed family characteristics are highly correlated with other, perhaps more fundamental, resources, such as parents' abilitywhich is again highly correlated with offspring's own ability, both through genetic and social transmission mechanisms. Why should this imply a weaker resource gradient in Figures 4 and 5 for immigrant children than for native children? A probable explanation is that the correlation between ability and earnings/education in the parent generation is much weaker 
Fig 4: Parental earnings and upper secondary school completion

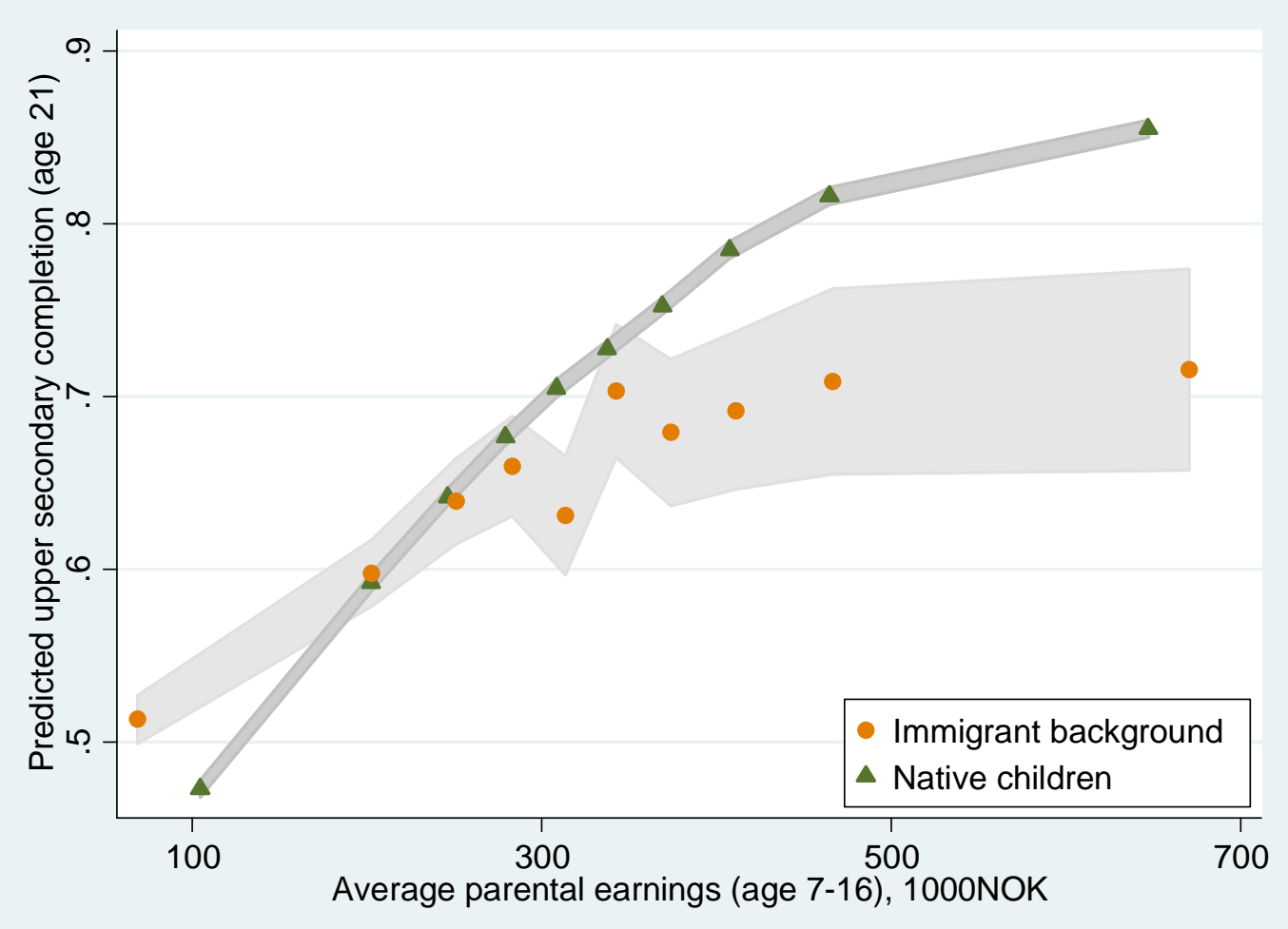

Note: Scatter points give the predicted completion rate and the sample mean of parental earnings within ten earnings brackets defined by year-specific deciles of the native earnings distribution. Shaded areas indicate 95 percent confidence intervals around the point estimates. Estimates are based on regression that controls for gender, 15 cohort effects, 131 country of origin effects, as well as born abroad and trends in immigrant completion (see Table 2, column 4). Immigrant intercept is evaluated at the weighted average of born abroad, time trends, and country effects.

for immigrants than for natives, as immigrant parents may not have had the same opportunity to accomplish their potential in the Norwegian labor market as natives, and because the variation in immigrant parental attainment also reflects differences in educational systems of source countries. ${ }^{10}$ If such explanations are correct, we would expect the difference in gradients to become smaller if we also control for the offspring's own ability. We return to this issue below.

Figures 4 and 5 show that children of immigrants have higher completion rates than native children at very low levels of parental earnings and education, but lower completion rates at high levels of parental earnings and education. It is therefore not clear how one would evaluate the difference between immigrant and native children when one controls for parental resources. One approach is to account for differences in impacts of parental resources, and to

\footnotetext{
${ }^{10}$ Differences in measurement error in the parental earnings and education variables might also yield weaker correlations for immigrants compared to natives.
} 
Fig 5: Parental education and upper secondary school completion

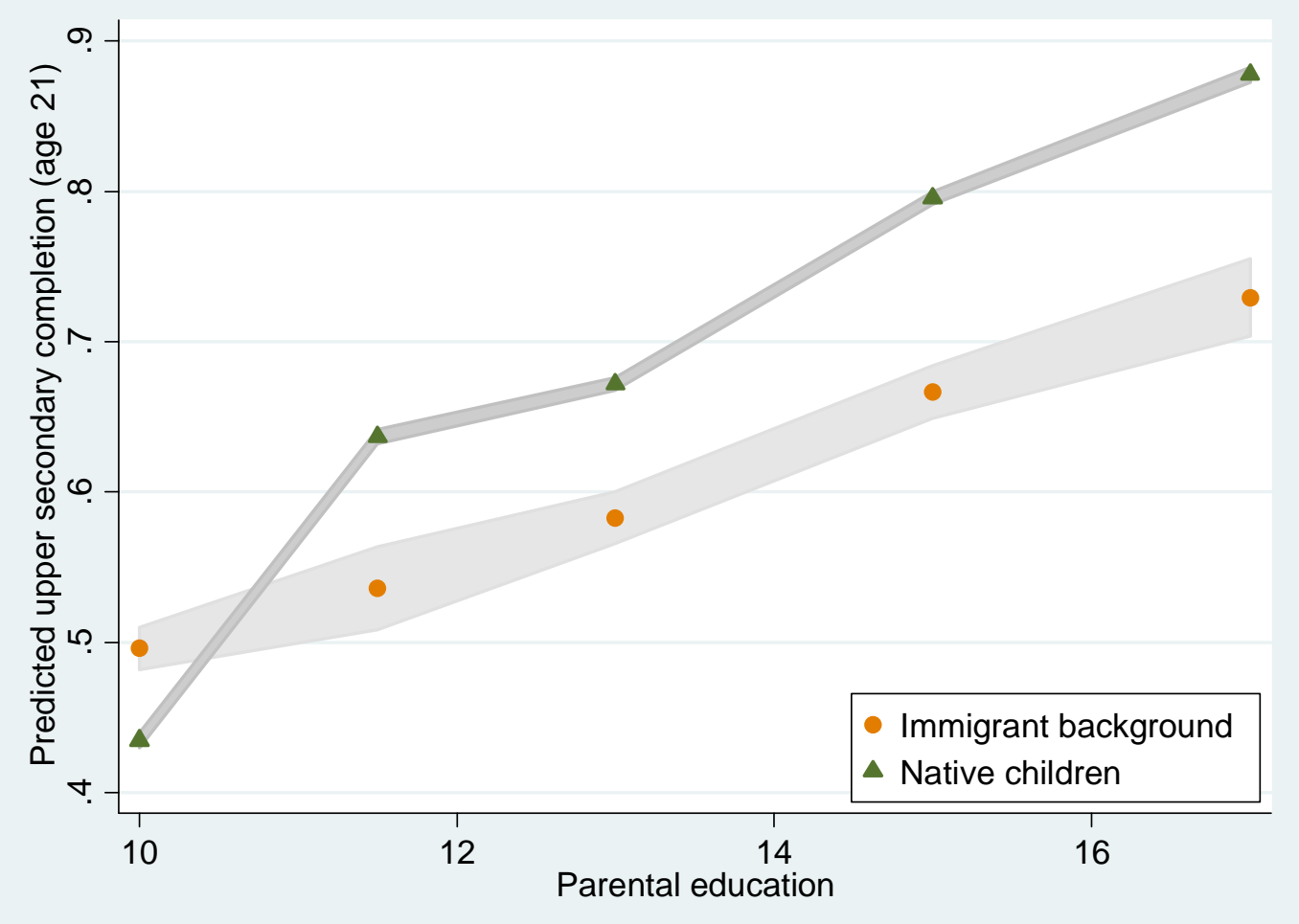

Note: Scatter points give the predicted completion rate for each of five levels of educational attainment, and shaded areas 95 percent confidence intervals around the point estimates. Parental education is measured as the highest attainment of mother and father. Regression controls for gender, 15 cohort effects, 131 country of origin effects, as well as born abroad and trends in immigrant completion (see Table 2, column 6). Immigrant intercept is evaluated at the weighted average of born abroad, time trends, and country effects.

evaluate the differential across the native parental distribution (in other words, create a counterfactual where immigrant children have exactly the same parental resource distribution as native children). This is the approach underlying the results reported in columns (4) and (6) of Table 2. We then find that immigrant-background children born in Norway on average perform approximately as natives when the differences in the distribution of parental resources are controlled for. Moreover, the estimate of the rate of catching-up becomes slightly larger than in the models that do not control for parental resources. The explanation for this finding is that immigrant parents have fallen behind native parents over time in the distribution of resources (particularly their earnings), which, ceteris paribus, has pulled the completion rates of immigrant youths downwards.

Although the controls for parental earnings and education go a long way in accounting for underlying differences in family resources, unobserved differences between immigrant and native families are bound to remain. One way to control even for unobserved family characteristics, is to estimate models with family fixed effects (i.e., a dummy variable for each 
family included in the data set). For this purpose, we obviously identify coefficients using families with more than one offspring in the data (otherwise all differences will be absorbed by the family fixed effect). Such a model can nevertheless be useful for two purposes; first, to obtain an unbiased estimate of the difference between immigrant-background children born in Norway and those born abroad (as some families contain both types of children), and second, to obtain unbiased estimates of catching-up trends (as we can compare siblings belonging to different graduation cohorts). The results from the model estimated with family fixed effects are reported in column (7). It should be noted that the reported average difference between immigrant-background children born in Norway and natives of 10.6 percentage points now incorporates differences due to, e.g., country of origin and family resources (i.e., nothing is “controlled away” in the estimated intercepts). The difference between immigrant-background children born in Norway and abroad is much smaller within than across families. To some extent, this reflects that childhood immigrants with siblings born in Norway tend to be relatively young at the time of arrival, and, as we will show below, this greatly improves their educational prospects. The most important result to emerge from column (7), however, is that the catching-up trend is even larger in this model than in the models where we only control for observed family characteristics. Hence, the finding of rapid convergence in completion rates for immigrant and native children appears to be a very robust result.

\subsection{The role and the determination of grade points in compulsory school}

As indicated above, an important methodological lesson to be learned from our analysis is that the common practice of "controlling for parental resources" without allowing these resources to affect immigrant and native children differently may lead to highly misleading inference. A possible reason for the discrepancy in family resource impacts between children of immigrant and native families is that these variables to some extent operate as proxies for unobserved abilities. If this is the case, we would expect the impact of family resources to become weaker and more equal, the more we are able to control for student ability. One way to (imperfectly) control for student ability is to condition the analysis of upper secondary school completion on the academic results obtained at the compulsory level. As explained in section 3, we have in our data access to grade points obtained in the last year of compulsory school only for the last four cohorts of the sample.

Table 3 presents regression results based on these four cohorts (note that we do not estimate catching-up trends in these models, as the four-year observation period is too short to make 
Table 3: Upper secondary completion, 2001-2004 cohorts

(1)

\begin{tabular}{|c|c|c|c|}
\hline Immigrant background & $\begin{array}{l}-.052 \\
(.009)\end{array}$ & $\begin{array}{l}.001 \\
(.008)\end{array}$ & $\begin{array}{l}-.018 \\
(.030)\end{array}$ \\
\hline Immigrant*Born abroad & -.098 & -.016 & -.021 \\
\hline Female & $\begin{array}{c}(.012) \\
.100 \\
(.002)\end{array}$ & $\begin{array}{l}(.010) \\
-.021 \\
(.002)\end{array}$ & $\begin{array}{c}(.038) \\
.008 \\
(.005)\end{array}$ \\
\hline Constant & $\begin{array}{l}.663 \\
.602)\end{array}$ & $\begin{array}{l}.193 \\
(.003)\end{array}$ & $\begin{array}{l}. .309 \\
.309 \\
(.009)\end{array}$ \\
\hline Grade points & & & \\
\hline $2^{\text {nd }}$ decile & & $\begin{array}{c}.201 \\
(.004)\end{array}$ & $\begin{array}{c}.151 \\
(.010)\end{array}$ \\
\hline $3^{\text {rd }}$ decile & & $\begin{array}{l}.004) \\
.351 \\
(.004)\end{array}$ & $\begin{array}{l}.0106 \\
.266 \\
(.011)\end{array}$ \\
\hline $4^{\text {th }}$ decile & & $\begin{array}{c}.476 \\
(.004)\end{array}$ & $\begin{array}{c}.358 \\
(.011)\end{array}$ \\
\hline $5^{\text {th }}$ decile & & $\begin{array}{l}.585 \\
(.004)\end{array}$ & $\begin{array}{c}.459 \\
(.011)\end{array}$ \\
\hline $6^{\text {th }}$ decile & & $\begin{array}{c}.662 \\
(.004)\end{array}$ & $\begin{array}{l}.516 \\
(.012)\end{array}$ \\
\hline $7^{\text {th }}$ decile & & $\begin{array}{c}.722 \\
(.004)\end{array}$ & $\begin{array}{l}.567 \\
(.012)\end{array}$ \\
\hline $8^{\text {th }}$ decile & & $\begin{array}{l}.764 \\
(.004)\end{array}$ & $\begin{array}{l}.578 \\
. .012)\end{array}$ \\
\hline $9^{\text {th }}$ decile & & $\begin{array}{l}.796 \\
(.004)\end{array}$ & $\begin{array}{l}.012 \\
.612)\end{array}$ \\
\hline $10^{\text {th }}$ decile & & $\begin{array}{l}.811 \\
(.004)\end{array}$ & $\begin{array}{l}.622 \\
(.013)\end{array}$ \\
\hline Controls & $\begin{array}{l}\text { Cohort + } \\
\text { Country }\end{array}$ & $\begin{array}{l}\text { Cohort + } \\
\text { Country }\end{array}$ & $\begin{array}{c}\text { Cohort }+ \\
\text { Family fixed effects }\end{array}$ \\
\hline
\end{tabular}

Note: Standard errors are listed in parentheses. The coefficient of "immigrant background" is computed as the difference between the sample mean fixed effects in the immigrant and native subsamples. There are 197,076 observations, except for in column (3) which is based on 49,615 children from 24,399 families with multiple siblings in the data. Samples are restricted to students with grade point data and cover 98 percent of the native and 97 percent of the immigrant-background children in the relevant cohorts.

such an exercise meaningful). A first point to note from the table is that controlling for grade points completely eliminates the difference in upper secondary school completion between immigrant children (of both types) and native children, even without controlling for family resources. When we also include family resources in these models, they turn out to have very moderate effects for natives, and no effects at all for children of immigrants-and, as expected, the difference between the two gradients become smaller. ${ }^{11}$ The grade point

\footnotetext{
${ }^{11}$ Out of space concerns, we do not report the coefficients of parental earnings intervals in tables. The estimated gradients between the lower and upper parts of the earnings distribution, represented by the difference between completion rates of children at the ninth and second deciles of the (native) earnings distribution and shown in Figure 4 to be 22 percentage points for native children and ten percentage points for immigrant children, become seven percentage points for native children and zero for immigrant children when we control for grade points.
} 
achievements in compulsory school, on the other hand, turn out to have a huge effect on the completion propensity. Comparing the estimated effects of grade points in column (2) (with controls for cohort and origin country only) and column (3) (which also includes family fixed effects), we note that the latter are significantly smaller. We interpret this as evidence that the grade point estimates reported in column (2) to some extent reflect the correlation between grade points and unobserved family resources and therefore contain an upward bias. Yet, the causal effect estimates reported in column (3) remain large; moving from the second to the ninth decile of the grade point distribution raises the completion probability by 46 percentage points.

Note that the coefficient of "female" switches sign between columns (1) and (2)—a pattern that calls for an interpretation. While girls in general have significantly higher completion rates than boys, accounting for their superior performance in terms of grade points at age 16 alters the gender differential and, conditional on grade points, boys appear to do better than girls in terms of upper secondary completion; see column (2). The latter result most likely reflects the large and probably inflated estimates of the effect of grade points on upper secondary completion in column (2). When estimated within families, as in column (3), there is no difference in completion rates between boys and girls once we control for grade points in compulsory school.

The regressions reported in Table 3 build on the assumption that grade points have the same influence on upper secondary completion for immigrant and native children. In light of our finding that family resources have very different effects for the two groups, a legitimate concern is that this restriction might be false. The assumption turns out to be valid, however. This is illustrated in Figure 6, where we show the estimated impacts of grade points when we allow these to differ for children of immigrants and natives (otherwise based on the models underlying in columns (2) and (3) of Table 3). The impacts are strikingly similar for immigrants and natives, both with and without family fixed effects included in the model.

What about the relationship between family resources and grade points? Given the argument that observed parental resources form a poorer proxy for ability among immigrants than among natives, we would expect the association between parental resources and offspring's grade points to be stronger among natives. And this is indeed the case; see Figure 7. 
Fig 6: Compulsory school grade points and completion of upper secondary education

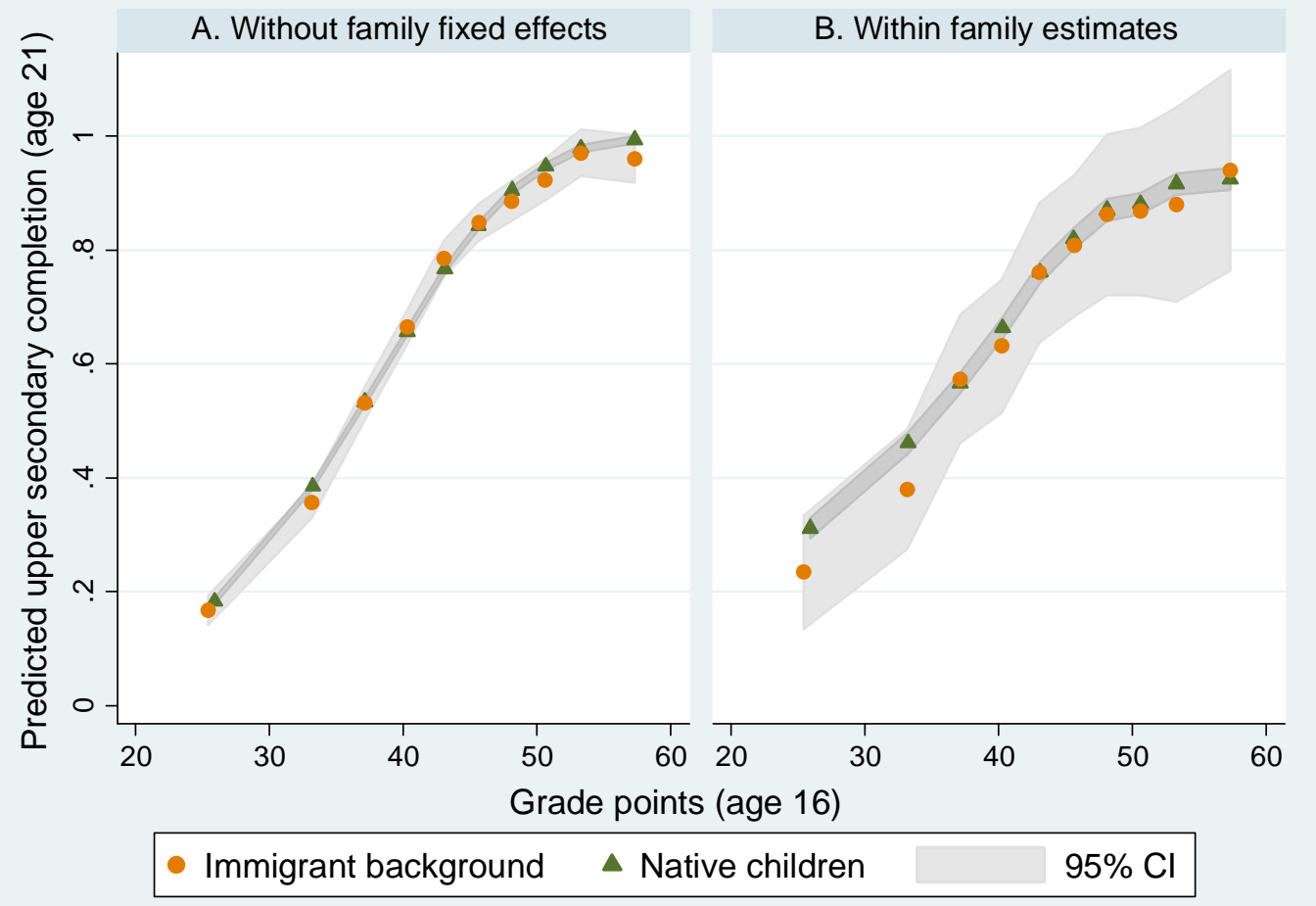

Note: Scatter points give the predicted upper secondary education completion rate and mean grade points for each of 10 intervals defined by deciles of the grade point distribution, and shaded areas indicate 95 percent confidence intervals around point estimates. Estimates in panel A are based on a regression that controls for gender, cohort, born abroad, and country fixed effects. Regression underlying panel B controls for gender, cohort, born abroad, and family fixed effects. See also Table 3, columns 2 and 3, which impose the additional restriction that the relationship between grade points and completion is the same for immigrants and natives.

More complete results from grade point regressions are provided in Table 4. In this table, we simply replicate the regression specifications underlying the columns in Table 2 above, only this time with grade points serving as the dependent variable instead of upper secondary school completion. The starting point is again a significant disadvantage for immigrantbackground children (see column 2). Controlling for parental resources with common coefficients (clearly the wrong model; refer back to Figure 7) again shifts the unconditional disadvantage towards a significant conditional advantage for Norwegian-born children of immigrant parents, particularly when the model includes parental earnings (column 3). But, using the more appropriate strategy of letting family resource coefficients vary between immigrant and native parents reduces the apparent advantage held by the native-born children of immigrants over other groups; see column (4). A robust result to emerge from Table 4 is that childhood immigrants achieve significantly lower grade points at age 16 than their peers born in Norway. In the next subsection, we take a closer look at the importance of arriving in Norway as a child, with a particular focus on the role of age at arrival. 
Fig 7: Parental education and compulsory school grade points

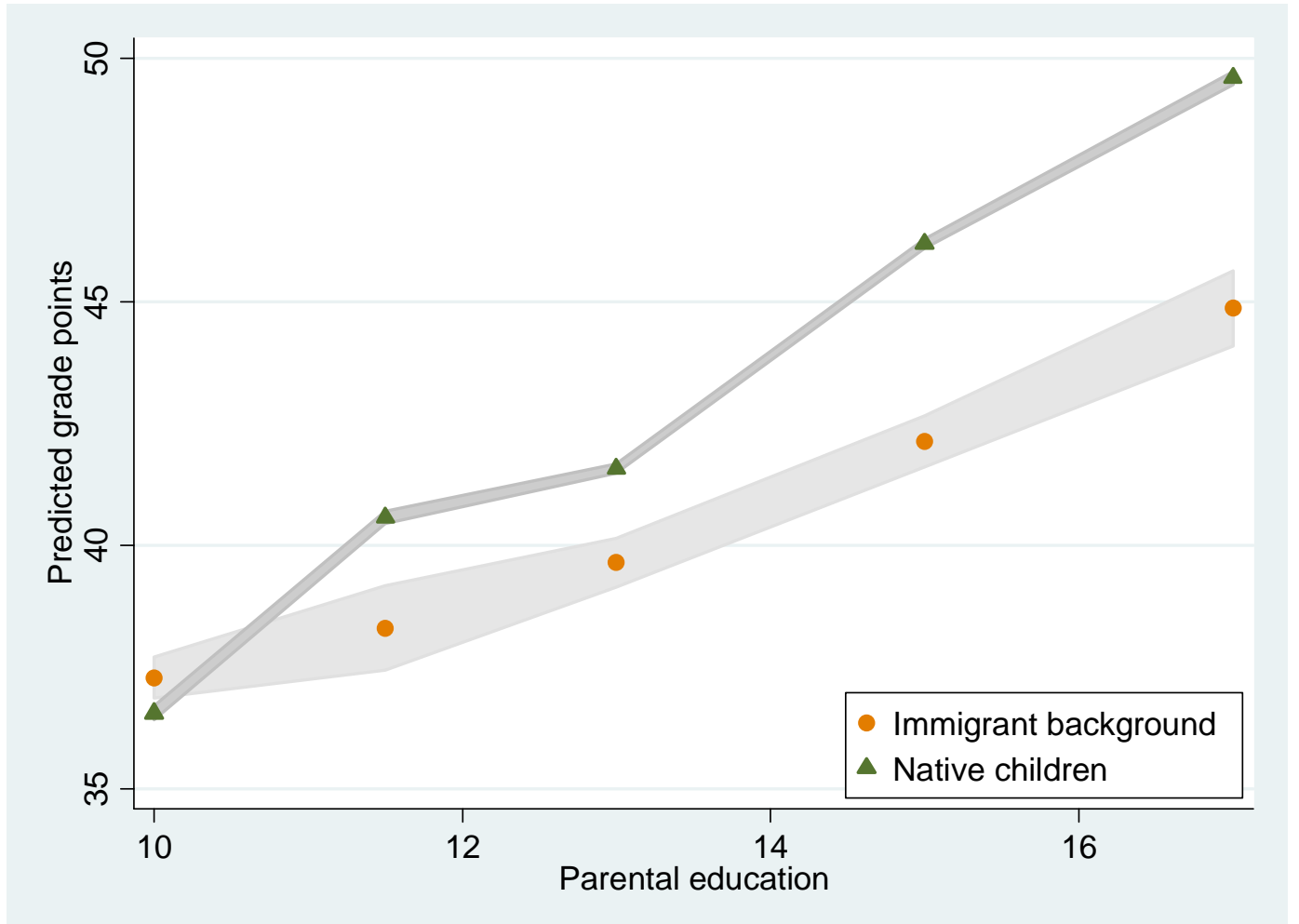

Note: Scatter points give predicted grade points for each of five levels of parental educational attainment and shaded areas 95 percent confidence intervals around the point estimates. See also notes to Figure 4 and Table 4.

Table 4: Grade points regressions, 2001-2004 cohorts

(1)

(2)

(3)

(4)

(5)

(6)

(7)

\begin{tabular}{|c|c|c|c|c|c|c|c|}
\hline $\begin{array}{l}\text { Immigrant } \\
\text { Background }\end{array}$ & $\begin{array}{l}-2.005 \\
(.145)\end{array}$ & $\begin{array}{l}-2.007 \\
(.185)\end{array}$ & $\begin{array}{l}1.031 \\
(.177)\end{array}$ & $\begin{array}{l}.450 \\
(.212)\end{array}$ & $\begin{array}{c}-567 \\
(.176)\end{array}$ & $\begin{array}{l}-1.703 \\
(.144)\end{array}$ & $\begin{array}{l}-2.790 \\
(.518)\end{array}$ \\
\hline Immigrant** & -2.900 & -2.898 & -1.734 & -1.948 & $\begin{array}{l}-1.804 \\
-1.804\end{array}$ & -2.244 & -1.467 \\
\hline Born abroad & $(.180)$ & (.229) & $(.217)$ & $(.221)$ & $(.211)$ & $(.212)$ & $(.651)$ \\
\hline Controls & $\begin{array}{c}\text { Gender + } \\
\text { Cohort }\end{array}$ & $\begin{array}{c}\text { Gender + } \\
\text { Cohort + } \\
\text { Country }\end{array}$ & $\begin{array}{c}\text { Gender + } \\
\text { Cohort + } \\
\text { Country + } \\
\text { Parental } \\
\text { earnings } \\
\text { (common } \\
\text { coeffs) }\end{array}$ & $\begin{array}{c}\text { Gender + } \\
\text { Cohort }+ \\
\text { Country + } \\
\text { Parental } \\
\text { earnings } \\
\text { (separate } \\
\text { coeffs) }\end{array}$ & $\begin{array}{c}\text { Gender + } \\
\text { Cohort + } \\
\text { Country + } \\
\text { Parental } \\
\text { education } \\
\text { (common } \\
\text { coeffs) }\end{array}$ & $\begin{array}{c}\text { Gender + } \\
\text { Cohort + } \\
\text { Country + } \\
\text { Parental } \\
\text { education } \\
\text { (separate } \\
\text { coeffs) }\end{array}$ & $\begin{array}{c}\text { Gender + } \\
\text { Cohort + } \\
\text { Family } \\
\text { fixed } \\
\text { effects }\end{array}$ \\
\hline
\end{tabular}

Note: Standard errors are listed in parentheses. Regressions have 197,076 observations, except for in column (7) which is based on 49,615 children from 24,399 families with multiple siblings in the data. In columns (4) and (6) the coefficient of "immigrant background" is averaged across ten income and five education levels, weighted by the native frequency distribution. See also notes to Tables 2 and 3. 


\subsection{Age at immigration}

For immigrant children born abroad, prior research based on Swedish and U.S. data shows that the age at which they actually enter the host country is of critical importance. To examine this issue, we have re-estimated the key regressions of the prior sections replacing the “immigrant born abroad” indicator with a complete set of dummy variables for each age at arrival; see Table 5. The listed coefficients give the estimated differential completion rate compared to an immigrant-background child born in Norway. The models are estimated with and without accounting for parental years of residence in Norway, separately for boys and girls, and, finally, in the limited sample with and without controlling for grade points from compulsory school.

As the first five columns show, completion rates decline sharply with age at arrival. For example, a childhood immigrant arriving at age 11 faces a 13 to 15 percentage point lower likelihood of completing upper secondary education compared to a child with an immigrant background but born in Norway. These estimates are robust whether or not we control for parental years since arrival and whether we look at boys or girls. But, as column (6) illustrates, the disadvantage of late arrival is fully accounted for by differences in compulsory school grade points.

One possible explanation for the catching-up in educational performance among immigrant children documented in prior sections and replicated in column (1) of Table 5, is that their parents over time have become more socially integrated into the Norwegian society or acquired better language skills due to longer residency in Norway. The results in columns (2)(6) examine this possibility by including parental years since migration in the regression models. As the columns show, parental time in the country has minimal effect on the offspring's educational performance, and accounting for parental years since arrival does not alter the estimated catching-up trend.

So far, we have not considered whether the empirical patterns of upper secondary education completion might differ by gender (other than noting that there is an overall advantage for girls of about ten percentage points that disappears when we account for grade points from compulsory school; refer back to Table 3). In Table 5, columns (3) and (4), the extended specification of the completion regression is estimated separately for boys and girls. The listed coefficients show that, in general, boys and girls face very similar coefficient structures. 
Table 5: The role of age at arrival

(1)

(2)

(3)

(4)

(5)

(6)

\begin{tabular}{|c|c|c|c|c|c|c|}
\hline \multicolumn{7}{|l|}{ Age at immigration } \\
\hline 0 & $\begin{array}{l}-0.034 \\
(0.023)\end{array}$ & $\begin{array}{l}-0.035 \\
(0.023)\end{array}$ & $\begin{array}{l}-0.025 \\
(0.033)\end{array}$ & $\begin{array}{l}-0.045 \\
(0.031)\end{array}$ & $\begin{array}{l}-0.028 \\
(0.029)\end{array}$ & $\begin{array}{l}-0.003 \\
(0.025)\end{array}$ \\
\hline \multirow[t]{2}{*}{1} & -0.051 & -0.053 & -0.041 & -0.067 & -0.070 & -0.037 \\
\hline & $(0.016)$ & $(0.016)$ & $(0.025)$ & $(0.022)$ & $(0.024)$ & $(0.021)$ \\
\hline \multirow[t]{2}{*}{2} & -0.059 & -0.061 & -0.048 & -0.069 & -0.034 & -0.018 \\
\hline & $(0.015)$ & $(0.015)$ & $(0.021)$ & $(0.021)$ & $(0.022)$ & $(0.019)$ \\
\hline \multirow[t]{2}{*}{3} & -0.065 & -0.068 & -0.062 & -0.076 & -0.087 & -0.037 \\
\hline & $(0.015)$ & $(0.015)$ & $(0.022)$ & $(0.021)$ & $(0.023)$ & $(0.020)$ \\
\hline \multirow[t]{2}{*}{4} & -0.064 & -0.067 & -0.075 & -0.059 & -0.075 & -0.045 \\
\hline & $(0.014)$ & $(0.015)$ & $(0.021)$ & $(0.020)$ & $(0.023)$ & $(0.020)$ \\
\hline \multirow[t]{2}{*}{5} & -0.080 & -0.084 & -0.092 & -0.074 & -0.077 & -0.027 \\
\hline & $(0.013)$ & $(0.014)$ & $(0.020)$ & $(0.020)$ & $(0.023)$ & $(0.019)$ \\
\hline \multirow[t]{2}{*}{6} & -0.081 & -0.085 & -0.096 & -0.071 & -0.084 & -0.034 \\
\hline & $(0.013)$ & $(0.014)$ & $(0.021)$ & $(0.020)$ & $(0.024)$ & $(0.020)$ \\
\hline \multirow[t]{2}{*}{7} & -0.085 & -0.090 & -0.092 & -0.085 & -0.088 & -0.033 \\
\hline & $(0.013)$ & $(0.015)$ & $(0.021)$ & $(0.020)$ & $(0.024)$ & $(0.021)$ \\
\hline \multirow[t]{2}{*}{8} & -0.100 & -0.106 & -0.097 & -0.114 & -0.080 & -0.017 \\
\hline & $(0.013)$ & $(0.015)$ & $(0.022)$ & $(0.021)$ & $(0.026)$ & $(0.022)$ \\
\hline \multirow[t]{2}{*}{9} & -0.093 & -0.099 & -0.120 & -0.072 & -0.167 & -0.045 \\
\hline & $(0.013)$ & $(0.016)$ & $(0.022)$ & $(0.022)$ & $(0.028)$ & $(0.024)$ \\
\hline \multirow[t]{2}{*}{10} & -0.126 & -0.132 & -0.159 & -0.100 & -0.146 & -0.010 \\
\hline & $(0.013)$ & $(0.016)$ & $(0.023)$ & $(0.022)$ & $(0.029)$ & $(0.025)$ \\
\hline \multirow[t]{2}{*}{11} & -0.148 & -0.155 & -0.158 & -0.153 & -0.129 & 0.011 \\
\hline & $(0.013)$ & $(0.016)$ & $(0.023)$ & $(0.023)$ & $(0.028)$ & $(0.024)$ \\
\hline \multirow[t]{2}{*}{12} & -0.147 & -0.154 & -0.181 & -0.125 & -0.140 & 0.011 \\
\hline & $(0.013)$ & $(0.016)$ & $(0.024)$ & $(0.023)$ & $(0.029)$ & $(0.024)$ \\
\hline \multirow[t]{2}{*}{13} & -0.164 & -0.171 & -0.202 & -0.138 & -0.133 & 0.031 \\
\hline & $(0.013)$ & $(0.017)$ & $(0.024)$ & $(0.024)$ & $(0.029)$ & $(0.025)$ \\
\hline \multirow[t]{2}{*}{ Immigrant backgr } & -.032 & -.021 & -.029 & -.013 & -.002 & .029 \\
\hline & $(.005)$ & $(.010)$ & $(.014)$ & $(.013)$ & $(.015)$ & $(.013)$ \\
\hline Immigrant backgr* & .068 & .071 & .075 & .066 & & \\
\hline Trend/10 & $(.012)$ & $(.013)$ & $(.018)$ & $(.017)$ & & \\
\hline Born abroad* & -.041 & -.044 & -.083 & -.004 & & \\
\hline Trend/10 & $(.015)$ & $(.016)$ & $(.023)$ & $(.022)$ & & \\
\hline Years since migr & & -.006 & -.013 & .002 & -.012 & -.010 \\
\hline parents/10 & & (.008) & $(.011)$ & $(.011)$ & $(.012)$ & $(.010)$ \\
\hline Observations & 736,845 & 736,845 & 376,858 & 359,987 & 197,076 & 197,076 \\
\hline $\begin{array}{l}\text { Control for grade } \\
\text { points? }\end{array}$ & No & No & No & No & No & Yes \\
\hline Sample & Full & Full & Boys & Girls & 2001-2004 & 2001-2004 \\
\hline
\end{tabular}


For example, the disadvantage of late arrival is quite similar by gender and for neither boys nor girls is there any effect of parental years of residence in Norway.

The one exception is that the, albeit moderate, catching-up trend for childhood immigrants uncovered in prior tables, appears to be limited to girls. In fact, results in Table 5 indicate that immigrant girls born abroad have benefitted from the same rising trend in upper secondary completion as their sisters born in Norway, whereas boys born abroad have not seen any rising trend in completion rates. If the positive trend in upper secondary completion is linked to early school interventions, these results appear to fit with findings elsewhere in the literature showing that early interventions may have larger effects for girls than for boys (Drange and Telle, 2010; Havnes and Mogstad, 2011). On the other hand, for those with an immigrant background but born in Norway, Table 5 documents positive and statistically significant trend coefficients for both genders and there is no difference between the estimates for boys and girls. This finding shows that the processes behind the more favorable outcomes for immigrant-background children over time are unlikely to be gender related.

Figures 8 and 9 give visual illustrations of the estimated age at immigration effects in the two models explaining upper secondary school completion (columns 6 and 7 of Table 2) and grade point achievement (columns 6 and 7 of Table 4). Again, all impact estimates are evaluated relative to immigrant-background children born in Norway (represented by the zero-line).

The figures reiterate the finding that age at immigration is of critical importance, with a particularly steep gradient after age seven, which was the school starting age for the cohorts covered in this analysis (the school starting age was reduced to six years in 1997). The righthand panels of the figures show estimates of age at arrival effects based on within-family comparisons of siblings (see Figures 8 and 9, panel B, and also Böhlmark, 2007). As is evident from the figures, within-family estimates are very imprecise, and with wide confidence intervals we are typically unable to reject both the null hypothesis that age at arrival does not matter and the null hypothesis that the true effect of age at arrival is given by the estimate in panel A, computed without family fixed effects. It should be acknowledged that within-family identification of the age-at-immigration effects underlying Figure 8 is thin as long as the model specification contains time trends, as it is difficult to attribute the higher 
Fig 8: Differential upper secondary completion of immigrant children born in Norway and abroad by age at immigration

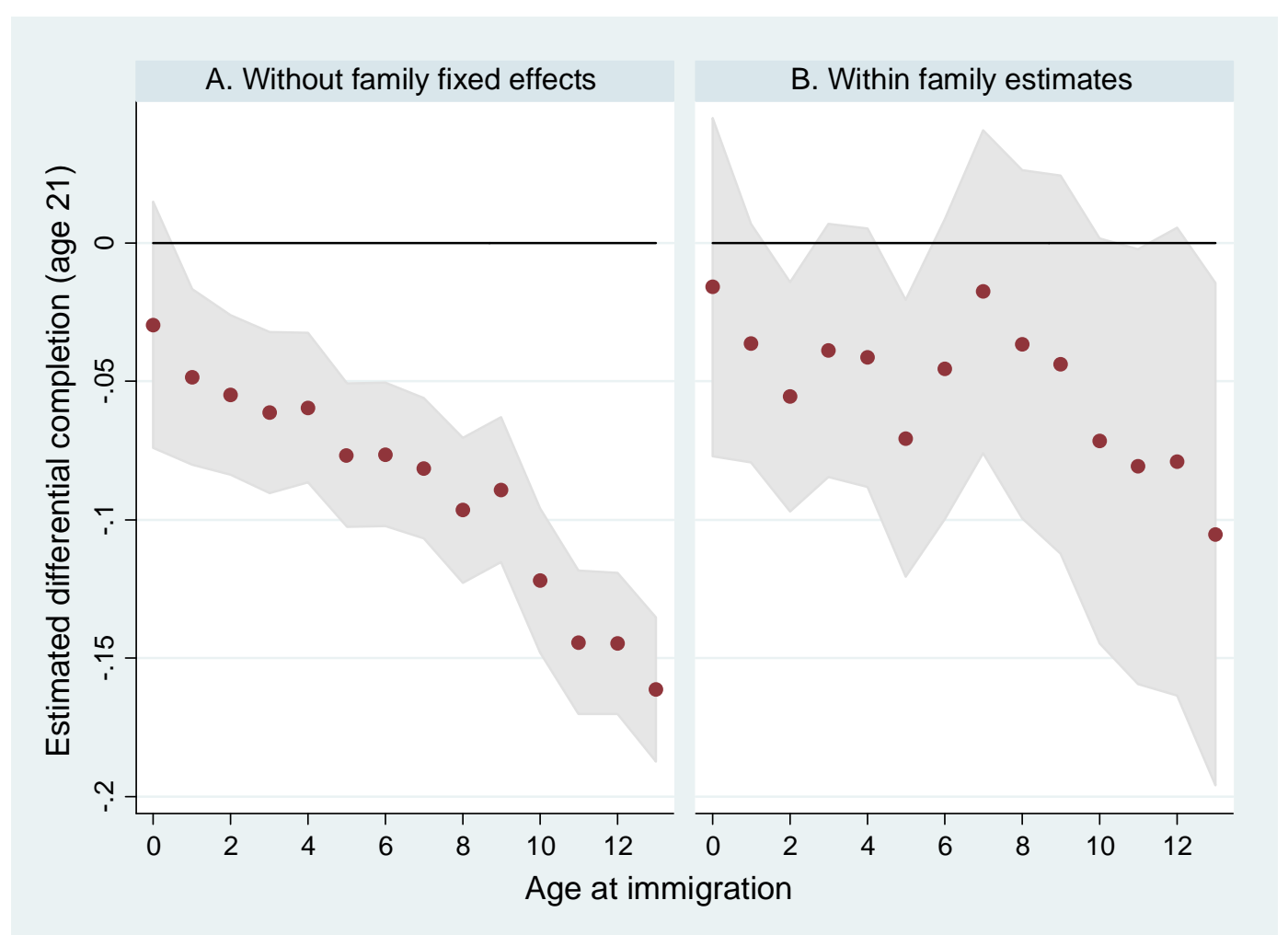

Note: Scatter points give the estimated difference in upper secondary education completion rates of immigrantbackground children born in Norway and those born abroad conditional on age at arrival, and shaded areas indicate 95 percent confidence intervals around point estimates. Estimates in panel A are based on a regression that controls for gender, parental education (5 levels plus missing), parental education interacted with immigrant background, 131 country fixed effects, 15 cohort effects, and time trends for immigrants born in Norway and abroad. Regression underlying panel B controls for gender, cohort, time trends, and family fixed effects. See also Table 2, columns 6 and 7 (which impose the restriction that completion rates do not vary with age at immigration).

completion rates of younger siblings to their younger age at arrival or to the underlying positive trend in completion rates for immigrant-background children. In fact, when we omit the trend variables from the within-family model, siblings-based coefficient estimates are very similar to those in panel A, paralleling the findings of Böhlmark (2007) based on Swedish data.

\subsection{Country of origin}

In the analyses so far, country of origin has only entered into our models as dummy control variables. We now briefly examine what the resultant estimated "country-specific effects" look like. Figure 10 shows the scatter plot of the country fixed effects estimated in the upper secondary school completion regression (Table 2, column 6) and those estimated in the 
Fig 9: Grade point differential between immigrant children born in Norway and abroad by age at immigration

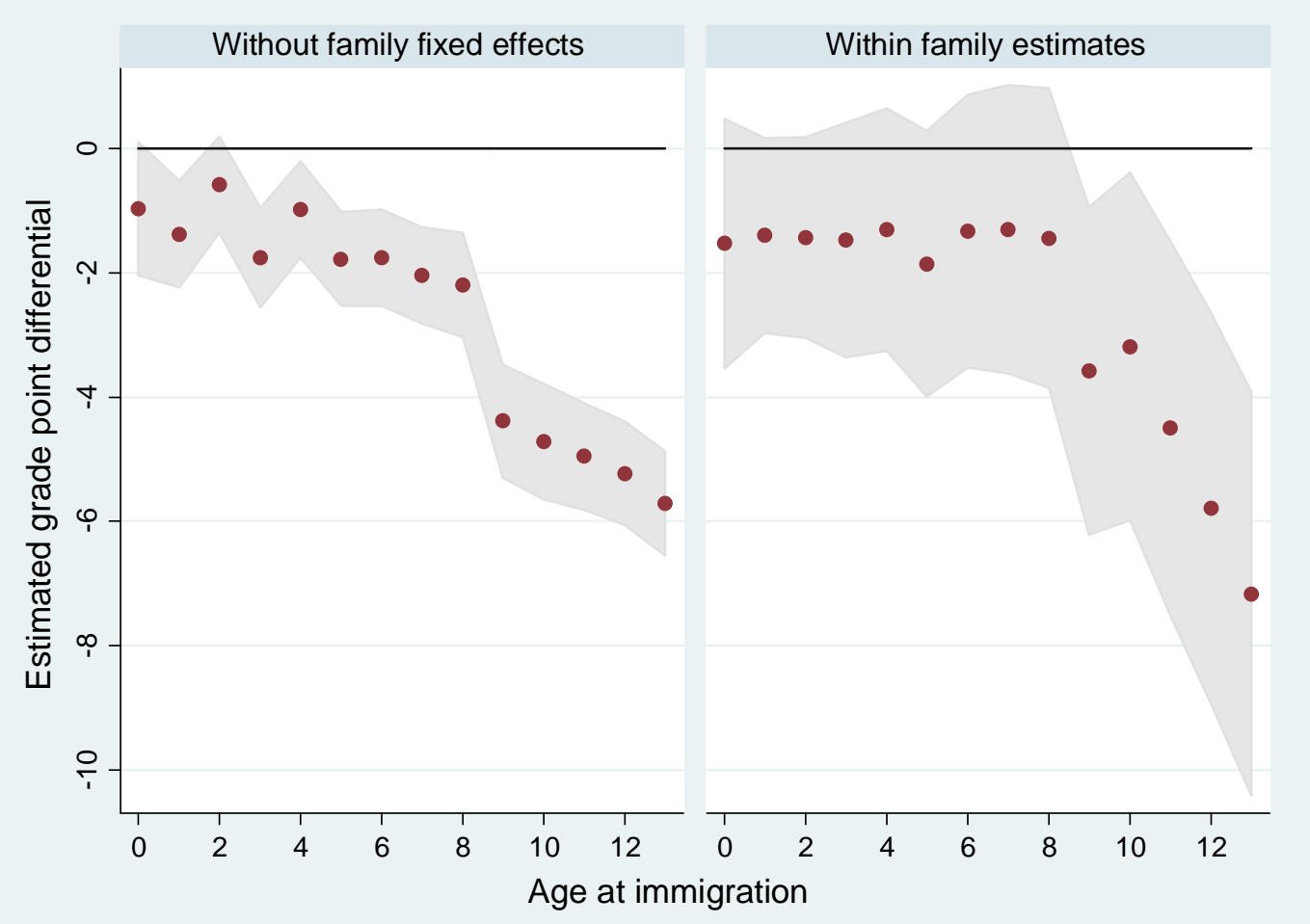

Note: Scatter points show the estimated difference in compulsory school grade points of immigrant-background children born in Norway and those born abroad conditional on age at arrival, and shaded areas indicate 95 percent confidence intervals around point estimates. See notes to Figure 8 and Table 4.

compulsory school grade points regression (Table 4, column 6). Scatter point values are scaled relative to the weighted average in the immigrant data. For example, the scatter point for Pakistan (labeled "PK") shows that children of Pakistani immigrants score 0.7 grade points below the sample average in the immigrant data, and that their upper secondary education completion rate is 0.033 ( 3.3 percentage points) below the average for children of immigrants (see also the fixed effect estimates listed in the appendix).

There are three points to note from the figure. The first is that there are huge differences in school outcomes across source countries. For example, the poorest performing groups (Somalia, Kosovo, Morocco, Chile, Iraq, and Turkey) have upper secondary school completion rates that are nine to twelve percentage points below the overall average for immigrant children, ceteris paribus, while the best performing groups (China, Bosnia and Herzegovina, Vietnam, and Sri Lanka) have completion rates that are 13 to 20 percentage points higher than the immigrant average. A second point to note is that the country-specific 
Fig 10: Country of origin heterogeneity

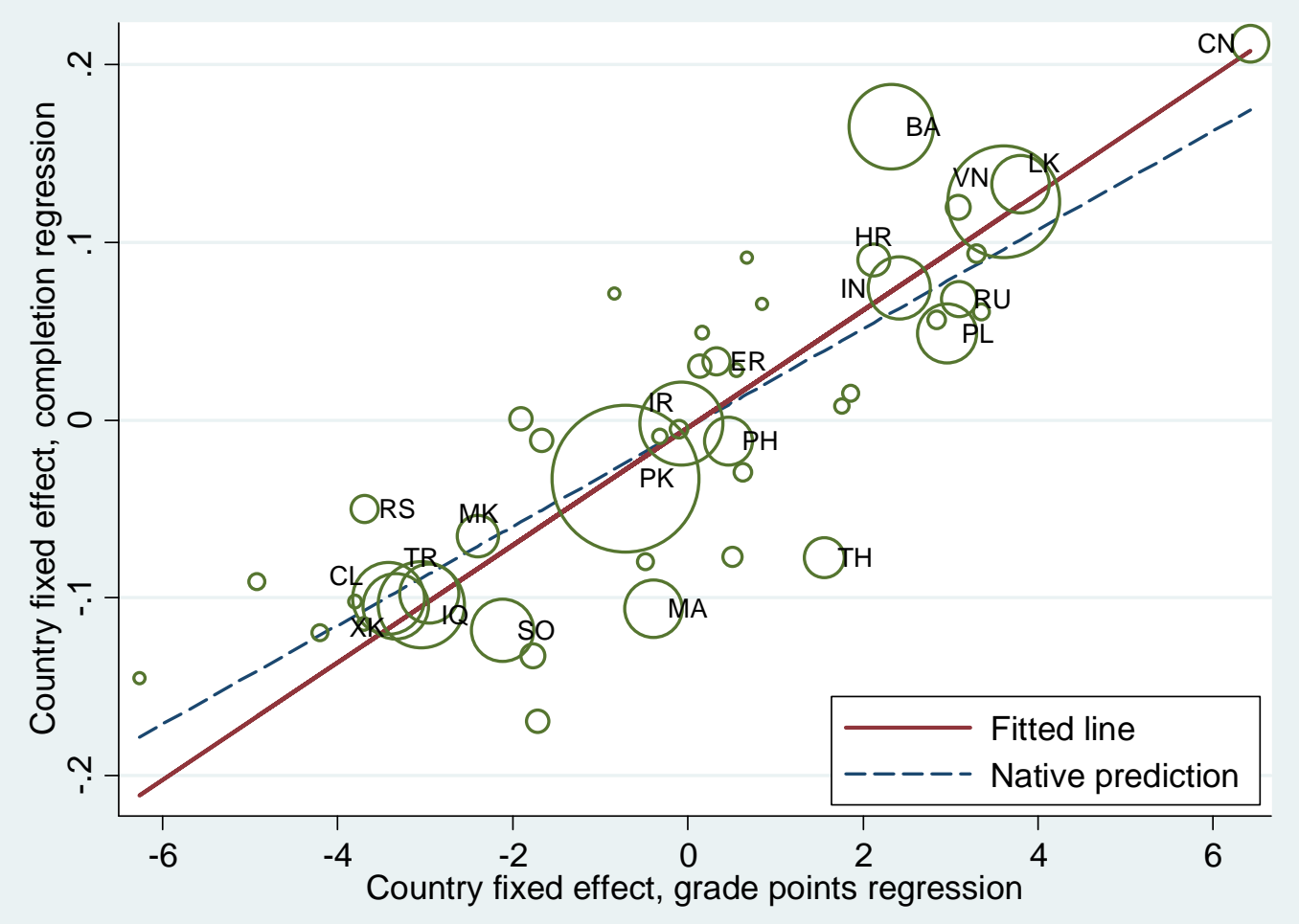

Note: Scatter points show the country-of-origin fixed effects from regressions presented in Table 2, column (6), and Table 4, column (6). Size of scatter point reflects cell size. Only cells with at least 30 observations are included.

fixed effects estimated in the grade point regression exhibit similar dispersion across source countries and that there is a strong positive correlation between the fixed effects estimated in the grade point regression and those estimated in the upper secondary education completion regression. And, finally, this relationship is virtually the same across source countries as it is for regression residuals among natives.

\section{Concluding remarks}

Children of immigrants constitute a rapidly growing share of school cohorts in Norway, with the Norwegian-born children of immigrant parents from the non-OECD area projected to account for ten percent of the cohort graduating from compulsory school by the year 2024 . The educational outcomes of immigrant children are important for future growth and inequality. Our study of the 15 cohorts that graduated from compulsory education between 1990 and 2004 shows that children of immigrants five years after compulsory school already have substantially higher educational attainments than their parents, suggesting that moving from a low to a high-income country indeed presents improved opportunities for education. 
Even so, children of immigrants are more likely to leave school early than children of natives, as the estimated average difference in completion rates from upper secondary education relative to native children is 16.7 percentage points for childhood immigrants and 8.0 percentage points for Norwegian-born children of immigrant parents. We find robust evidence, however, of a positive trend for immigrant-background children with a catching-up rate of 0.7 percentage point per year for those born in Norway. Such developments have contributed importantly to a marked reduction in the attainment gap between immigrant and native children over time. In fact, the difference in upper secondary education completion rates among Norwegian-born children of native and immigrant parents declined from 13 percentage points in the 1992-1994 compulsory school graduating cohorts to four percentage points in the 2002-2004 cohorts. For children born abroad, we find that completion rates decline sharply with age at immigration. This pattern holds for boys and girls, within families (between siblings), and controlling for parental years of residence in Norway.

For the four most recent cohorts of our sample, the data include school performance marks at the end of compulsory education. Children of immigrants obtain lower scores and controlling for grade points completely eliminates the observed differences in upper secondary school completion between immigrant-background and native children, even without accounting for differences in parental earnings and education. The disadvantage of late arrival is also fully accounted for by differences in compulsory school grade points.

Policy conclusions are bound to be speculative as our empirical analyses are not designed to identify causal effects of educational reforms or policies. Nonetheless, the patterns we uncover do suggest that policy initiatives aimed at improving immigrant children's educational performance — such as allocation of extra resources to target schools and to child care institutions in communities with high minority densities - may actually have contributed to a relative improvement in educational outcomes of children of immigrant parents. Prior studies provide strong indications that differential resource allocation across schools plays an important compensating role in the Norwegian educational system. Schools with high shares of disadvantaged pupils in terms of family background tend to have higher teacher-pupil ratios than other schools (Hægeland et al., 2004), and schools with many children of immigrant background have a higher incidence of teacher's aides for special needs pupils (Hægeland et al., 2009). Further, Hægeland et al. (2008) identify a positive influence of additional school resources on pupil performance at age 16, and Havnes and Mogstad (2011) 
show that the large-scale expansion of subsidized child care in Norway during the late 1970s and 1980s had strong positive effects on children’s educational attainment.

Of particular relevance is the finding of Drange and Telle (2010) that the introduction of free core-hour child care in school districts with high immigrant densities led to improved school outcomes of children from immigrant families when compared to developments in districts without free child care. The cohorts under study experienced a marked expansion of subsidized child care institutions nationwide, with child care coverage for three to six year olds increasing from below 30 percent for the oldest cohorts to above 60 percent for the youngest cohorts of our analysis data (Havnes and Mogstad, 2011). It is possible that the child care expansion had a greater impact on subsequent educational outcomes of children of nonOECD immigrant parents than native children, even if immigrant parents use pre-school child care less than native parents. In general, policies and interventions targeted at youth at risk of early school leaving are likely to have disproportionally positive effects for children of immigrants. Consistent with this view, Brinch et al. (2008) conclude that the 1994 reform granting entitlement to upper secondary education for all compulsory school graduates brought about a greater boost in the transition rate from compulsory to upper secondary education for immigrant youth than for native youth. Our empirical evidence therefore broadly harmonizes with an emerging European literature pointing to a role of the educational system in reducing disparities within the immigrant population as well as between children of immigrant and native parents (Dustmann et al 2010; Schneeweis, 2011).

Issues of integration of immigrants from low-income countries extend beyond schooling, and it remains to be seen whether the positive trends in educational attainment documented in this study are transmitted into more favorable labor market outcomes as growing numbers of immigrant children enter their 30s. Evidence from other countries indicates that, in spite of comparable and even superior education, wages and employment outcomes among children of immigrants often fall substantially below those of their majority-background classmates. 


\section{References}

Algan, Yann, Christian Dustmann, Albrecht Glitz and Alan Manning (2010), The Economic Situation of First and Second Generation Immigrants in France, Germany and the United Kingdom, The Economic Journal 120 (February), F4-F30.

Åslund, Olof, and Dan-Olof Rooth (2007), Do When and Where Matter? Initial Labor Market Conditions and Immigrant Earnings, The Economic Journal, Vol. 117, Issue 518, 422448.

Bauer, Philipp, and Regina T. Riphahn (2007), Heterogeneity in the intergenerational transmission of educational attainment: Evidence from Switzerland on natives and second-generation immigrants, Journal of Population Economics 20(1), 121-148.

Bauer, Thomas K., Magnus Lofstrom, and Klaus F. Zimmermann (2000), Immigration policy, assimilation of immigrants, and natives' sentiments towards immigrants: Evidence from 12 OECD countries, Swedish Economic Policy Review 7:11-53.

Barth, Erling, Bernt Bratsberg, and Oddbjørn Raaum (2004), Identifying Earnings Assimilation of Immigrants under Changing Macroeconomic Conditions, Scandinavian Journal of Economics, Vol. 106, No. 1, 1-22.

Björklund, Anders, and Kjell G. Salvanes (2011), Education and Family Background: Mechanisms and Policies, in Eric A. Hanushek, Stephen Machin, and Ludger Woessmann (eds), Handbook of Education Economics Vol 3, 201-247.

Blau, Francine D., Lawrence M. Kahn, and Kerry L. Papps (2008), Gender, source country characteristics and labor market assimilation among immigrants, 1980-2000, NBER Working Paper 14387.

Bleakley, Hoyt, and Aimee Chin (2004), Language Skills and Earnings: Evidence from Childhood Immigrants, Review of Economics and Statistics 86(2), 481-496.

Böhlmark, Anders (2008), Age at immigration and school performance: A siblings analysis using Swedish register data, Labour Economics 15, 1366-1387.

Böhlmark, Anders (2009), Integration of Childhood Immigrants in the Short and Long Run Swedish Evidence, International Migration Review 43(2), 387-409.

Borjas, George J. (1994), Long-Run Convergence of Ethnic Skill Differentials: The Children and Grandchildren of the Great Migration, Industrial and Labor Relations Review 47(4), 553-573.

Borjas, George J. (2006), Making It in America: Social Mobility in the Immigrant Population, The Future of Children 16(2), 55-71.

Bratsberg, Bernt, Oddbjørn Raaum, and Knut Røed (2010a), When Minority Labor Migrants meet the Welfare State, Journal of Labor Economics 28(3), 633-676. 
Bratsberg, Bernt, Oddbjørn Raaum, Knut Røed, and Hege Marie Gjefsen (2010b) Utdanningsog arbeidskarrierer hos unge voksne: Hvor havner ungdom som slutter skolen i ung alder? Frisch Centre Report 3/2010.

Bratsberg, Bernt, Oddbjørn Raaum, and Kjetil Sørlie (2007), Foreign-born Migration to and from Norway, in Caglar Ozden and Maurice Schiff (eds.), International Migration, Economic Development, \& Policy, New York: World Bank and Palgrave Macmillan.

Bratsberg, Bernt, and James F. Ragan, Jr. (2002), The Impact of Host-Country Schooling on Earnings-A Study of Male Immigrants in the United States, Journal of Human Resources 37(1), 63-105.

Bratsberg, Bernt, Knut Røed, Oddbjørn Raaum, Robin Naylor, Markus Jäntti, Tor Eriksson, and Eva Österbacka (2007), Nonlinearities in Intergenerational Earnings Mobility: Consequences for Cross-Country Comparisons, The Economic Journal 117(519), C72-92.

Brinch, Christian, Bernt Bratsberg, and Oddbjørn Raaum (2008), The Effects of an Upper Secondary Education Reform on the Attainment of Immigrant Youth, Discussion Paper No. 528, Statistics Norway.

Card, David (2004), Is the new immigration really so bad? The Economic Journal 115(507): 300-323.

Card, David, John DiNardo, and Eugena Estes (2000), The More Things Change: Immigrants and the Children of Immigrants in the 1940s, the 1970s and the 1990s, in Borjas, George (ed), Issues in the Economics of Immigration, University of Chicago Press.

Card, David, and Christoph M. Schmidt (2003), Editorial: Symposium on "Second-generation immigrants and the transition to ethnic minorities," Journal of Population Economics 16(4), 707-710.

Chiswick, Barry R., and Noyna DebBurman (2004), Educational attainment: Analysis by immigrant generation, Economics of Education Review 23(4), 361-379.

Cortes, Kalena E. (2006), The Effects of Age at Arrival and Enclave Schools on the Academic Performance of Immigrant Children, Economics of Education Review 25(2):121-132.

Dagsvik, John K., Torbjørn Hægeland, and Arvid Raknerud (2011), Estimating the returns to schooling: a likelihood approach based on normal mixtures, Journal of Applied Econometrics 26(4), 613-640.

Drange, Nina, and Kjetil Telle (2010), The effect of preschool on the school performance of children from immigrant families. Results from an introduction of free preschool in two districts in Oslo, Discussion Papers No. 631, Statistics Norway.

Dustmann, Christian, and Albrecht Glitz (2011), Migration and Education, in Eric A. Hanushek, Stephen Machin, and Ludger Woessmann (eds), Handbook of Education Economics Vol 4, 327-439. 
Dustmann, Christian, Tomasso Frattini, and Gianandrea Lanzara (2011), Educational Achievement of Second Generation Immigrants: An International Comparison, CReAM Discussion Paper No 16/11. Forthcoming in Economic Policy.

Dustmann, Christian, Steve Machin, and Uta Schönberg (2010), Ethnicity and Educational Achievement in Compulsory Schooling, The Economic Journal 120 (August), F272F297.

Fekjær, Silje N. (2007), New differences, old explanations. Can educational differences between ethnic groups be explained by social background? Ethnicities 7(3), 367-389.

Gonzalez, Arturo (2003), The education and wages of immigrant children: the impact of age at arrival, Economics of Education Review 22(2), 203-212.

Havnes, Tarjei, and Magne Mogstad (2011), No Child Left Behind: Subsidized Child Care and Children's Long-Run Outcomes, American Economic Journal: Economic Policy 3(2): 97-129.

Holmlund, Helena, Mikael Lindahl, and Erik Plug (2011), The Causal Effect of Parents' Schooling on Children's Schooling: A Comparison of Estimation Methods, Journal of Economic Literature 49(3), 615-651.

Hægeland, Torbjørn, Oddbjørn Raaum, and Kjell Gunnar Salvanes (2004), Pupil achievement, school resources and family background, Statistics Norway Discussion Papers, No. 397.

Hægeland, Torbjørn, Oddbjørn Raaum, and Kjell Gunnar Salvanes (2008) Pennies from heaven: Using exogenous tax variation to identify the effect of school resources on pupil achievement, IZA DP 3561.

Hægeland, Torbjørn, Lars J. Kirkebøen, and Oddbjørn Raaum (2009), Øre for læringRessurser i grunnskole og videregående opplæring i Norge 2003-2008, Frisch Centre Report 2/2009.

Liebig, Thomas, and Sarah Widmaier (2009), Children of Immigrants in the Labour Markets of EU and OECD Countries: An Overview, OECD Social Employment and Migration Working Papers No 97, OECD Publishing.

Markussen, Eifred, Mari W. Frøseth and Nina Sandberg (2011), Reaching for the Unreachable: Identifying Factors Predicting Early School Leaving and Non-Completion in Norwegian Upper Secondary Education, Scandinavian Journal of Educational Research 55(3), 225-253.

Nielsen, Helena Skyt, Michael Rosholm, Nina Smith, and Leif Husted (2003), The school-towork transition of 2nd generation immigrants in Denmark, Journal of Population Economics 16(4), 755-786.

OECD (2011), Education at a Glance 2011: OECD Indicators, OECD Publishing. 
Raaum, Oddbjørn, Bernt Bratsberg, Knut Røed, Eva Österbacka, Tor Eriksson, Markus Jäntti, and Robin A. Naylor (2007), Marital Sorting, Household Labor Supply, and Intergenerational Earnings Mobility across Countries, The B.E. Journal of Economic Analysis and Policy (Advances) 7(2), 2007, Article 7.

Raaum, Oddbjørn, Jon Rogstad, Knut Røed, and Lars Westlie (2009), Young and out: An application of a prospects-based concept of social exclusion, The Journal of SocioEconomics 38, 173-187.

Reisel, Liza, and Idunn Brekke (2010), Minority Dropout in Higher Education: A Comparison of the United States and Norway using Competing Risk Event History Analysis, European Sociological Review 26(6), 691-712.

Riphahn, Regina T. (2003), Cohort effects in the educational attainment of second generation immigrants in Germany: An analysis of census data, Journal of Population Economics 16(4), 711-737.

Sarvimäki, Matti (2011), Assimilation to a Welfare State: Labor Market Performance and Use of Social Benefits by Immigrants to Finland, Scandinavian Journal of Economics, 113(3), 665-688

Schneeweis, Nicole (2011), Educational institutions and the integration of migrants, Journal of Population Economics 24(4), 1281-1308.

Schnepf, Sylke Viola (2007), Immigrant's educational disadvantage: an examination across ten countries and three surveys, Journal of Population Economics 20, 527-545.

Støren, Liv Anne, and Håvard Helland (2010), Ethnic Differences in the Completion Rates of Upper Secondary Education: How Do the Effects of Gender and Social Background Interplay? European Sociological Review 26(5), 585-601.

Sweetman, Arthur, and Gordon Dicks (1999), Education and Ethnicity in Canada. An Intergenerational Perspective, Journal of Human Resources 34(4), 659-696.

Trejo, Stephen J. (2003), Intergenerational Progress of Mexican-Origin Workers in the U.S. Labor Market, Journal of Human Resources 38(3), 467-489.

Urban, Susanne (2011), University education as a compensating strategy among second generation immigrants, International Migration Review, forthcoming.

Van Ours, Jan, and Justus Veenman (2003), The educational achievement of secondgeneration immigrants in the Netherlands, Journal of Population Economics 16, 739753.

Vangen, Torill (2007), Nasjonal utdanningsdatabase NUDB, Dokumentasjonsrapport: Datavarehus for utdanningsdata, 1970-2006, Statistics Norway Notater 207/54.

Zhou, Min (1997), Growing Up American: The Challenge Confronting Immigrant Children and Children of Immigrants, Annual Review of Sociology 23, 63-95. 
Appendix: Labels and scatter point values for major countries listed in Figures 2 and 10

\begin{tabular}{|c|c|c|c|c|c|c|c|c|c|c|}
\hline \multirow[b]{2}{*}{ Label } & \multirow[b]{2}{*}{ Country } & \multicolumn{3}{|c|}{$\begin{array}{l}\text { Figure 2, panel A } \\
\text { (born in Norway) }\end{array}$} & \multicolumn{3}{|c|}{$\begin{array}{l}\text { Figure 2, panel B } \\
\text { (born abroad) }\end{array}$} & \multicolumn{3}{|c|}{ Figure 10} \\
\hline & & $\begin{array}{l}\text { Cmpl } \\
\text { rate } \\
\text { child } \\
(1)\end{array}$ & $\begin{array}{l}\text { Cmpl } \\
\text { rate } \\
\text { prnts } \\
(2)\end{array}$ & $\begin{array}{c}\text { Cell } \\
\text { size } \\
(3)\end{array}$ & $\begin{array}{l}\text { Cmpl } \\
\text { rate } \\
\text { child } \\
(4)\end{array}$ & $\begin{array}{l}\text { Cmpl } \\
\text { rate } \\
\text { prnts } \\
(5)\end{array}$ & $\begin{array}{c}\text { Cell } \\
\text { size } \\
(6) \\
\end{array}$ & $\begin{array}{c}\text { Cmpl } \\
\text { reg } \\
\text { fixed } \\
\text { effect } \\
(7) \\
\end{array}$ & $\begin{array}{l}\text { Grade } \\
\text { points } \\
\text { fixed } \\
\text { effect } \\
(8)\end{array}$ & $\begin{array}{l}\text { Obs } \\
(9)\end{array}$ \\
\hline HR & Croatia & 0.726 & 0.427 & 117 & 0.596 & 0.816 & 136 & 0.090 & 2.124 & 253 \\
\hline PL & Poland & 0.749 & 0.890 & 227 & 0.661 & 0.786 & 660 & 0.049 & 2.965 & 887 \\
\hline RU & Russia & & & & 0.637 & 0.750 & 320 & 0.068 & 3.100 & 321 \\
\hline TR & Turkey & 0.494 & 0.195 & 815 & 0.376 & 0.164 & 1079 & -0.104 & -3.048 & 1894 \\
\hline BA & Bosnia Herz & 0.760 & 0.540 & 50 & 0.737 & 0.817 & 1762 & 0.165 & 2.327 & 1812 \\
\hline MK & Macedonia & 0.537 & 0.306 & 147 & 0.482 & 0.528 & 282 & -0.065 & -2.401 & 429 \\
\hline $\mathrm{RS}$ & Serbia & 0.575 & 0.552 & 87 & 0.505 & 0.676 & 105 & -0.050 & -3.691 & 192 \\
\hline XK & Kosovo & 0.561 & 0.390 & 41 & 0.435 & 0.616 & 1053 & -0.105 & -3.336 & 1094 \\
\hline ER & Eritrea & 0.695 & 0.729 & 59 & 0.541 & 0.369 & 122 & 0.033 & 0.325 & 181 \\
\hline MA & Morocco & 0.495 & 0.180 & 471 & 0.364 & 0.162 & 346 & -0.106 & -0.390 & 817 \\
\hline SO & Somalia & & & & 0.365 & 0.364 & 931 & -0.118 & -2.115 & 953 \\
\hline LK & Sri Lanka & 0.790 & 0.824 & 176 & 0.659 & 0.412 & 663 & 0.133 & 3.802 & 839 \\
\hline $\mathrm{PH}$ & Philippines & 0.727 & 0.936 & 220 & 0.565 & 0.707 & 375 & -0.012 & 0.459 & 595 \\
\hline IN & India & 0.769 & 0.763 & 727 & 0.639 & 0.589 & 263 & 0.074 & 2.414 & 990 \\
\hline IQ & Iraq & & & & 0.423 & 0.508 & 852 & -0.098 & -2.957 & 863 \\
\hline IR & Iran & 0.693 & 0.893 & 75 & 0.566 & 0.678 & 1658 & -0.002 & -0.078 & 1733 \\
\hline $\mathrm{CN}$ & China & 0.815 & 0.531 & 81 & 0.764 & 0.524 & 254 & 0.211 & 6.422 & 335 \\
\hline PK & Pakistan & 0.586 & 0.356 & 3691 & 0.469 & 0.263 & 1712 & -0.033 & -0.713 & 5403 \\
\hline $\mathrm{TH}$ & Thailand & & & & 0.410 & 0.256 & 390 & -0.077 & 1.554 & 406 \\
\hline VN & Vietnam & 0.741 & 0.410 & 1023 & 0.639 & 0.297 & 2153 & 0.123 & 3.608 & 3176 \\
\hline CL & Chile & 0.516 & 0.799 & 219 & 0.491 & 0.723 & 1065 & -0.100 & -3.423 & 1284 \\
\hline
\end{tabular}

